\title{
Cyclical Fiscal Policy, Output Volatility, and Economic Growth
}

\author{
HARALD BADINGER
}

CESIFO WORKING PAPER No. 2268

CATEGORY 5: FiscAl PoliCy, MACROECONOMICS AND GROWTH APRIL 2008

\footnotetext{
An electronic version of the paper may be downloaded

- from the SSRN website:

www.SSRN.com

- from the RePEc website:

- from the CESifo website:

Www.RePEc.org

www.CESifo-group.org/wp
} 


\title{
Cyclical Fiscal Policy, Output Volatility, and Economic Growth
}

\begin{abstract}
This paper provides a comprehensive empirical assessment of the relation between the cyclicality of fiscal policy, output volatility, and economic growth, using a large cross-section of 88 countries over the period 1960 to 2004. Identification of the effects of (endogenous) cyclical fiscal policy is achieved by exploiting the exogeneity of countries' political and institutional characteristics, which we find to be relevant determinants of fiscal cyclicality. There are three main results: First, both pro- and countercyclical fiscal policy amplify output volatility, much in a way like pure fiscal shocks that are unrelated to the cycle. Second, output volatility, due to variations in cyclical and discretionary fiscal policy, is negatively associated with economic growth. Third, there is no direct effect of cyclicality of economic growth other than through output volatility. These findings advocate the introduction of fiscal rules that limit the use of (discretionary and) cyclical fiscal policy to improve growth performance by reducing volatility.
\end{abstract}

JEL Code: E3, E6, H3, H8.

Keywords: cyclical fiscal policy, output volatility, economic growth, institutions.

\author{
Harald Badinger \\ Department of Economics \\ Vienna University of Economics and Business Administration \\ Althanstrasse 39 - 45 \\ 1090 Vienna \\ Austria \\ harald.badinger@wu-wien.ac.at
}

March 2008

This paper was written during my stay as Erwin-Schrödinger Research Fellow at the Center for Economic Studies (CES), University of Munich. Financial support by the Austrian Science Fund (FWF) is gratefully acknowledged. 


\section{Introduction}

Does fiscal policy affect economic growth? This is clearly one of the most fundamental and policy relevant macroeconomic questions. Easterly (2005) argues that there is no robust evidence for a relation between macroeconomic policies (including fiscal policy) and economic growth, once institutions are controlled for. A similar point is made by Acemoglu et al. (2003). Yet this is not the predominant view. As Caballero (2008, p. 1) states more representatively: "Good macroeconomic policy helps growth ... I do not think this view is in any dispute in the applied and policy world.”

Notwithstanding the wide agreement that macroeconomic policies can influence economic performance, it remains a challenge for both theory and empirics to identify the channels through which economic policy affects growth. The emergence of new endogenous growth theory, overcoming the traditional dichotomy between business cycle theory on the one hand and growth theory on the other hand, has laid the ground for such an analysis. It is hardly questioned that economic policy affects economic activity in the short run. But then, if business cycle volatility and economic growth are related as suggested by endogenous growth theory, economic policy can indirectly affect growth through its effect on the (volatility of the) business cycle. Such a finding would also lead to a reassessment of macroeconomic priorities: The welfare cost of volatility per se are widely regarded as negligible since Lucas (1987). But if volatility turns out to have a negative effect on economic growth, its costs - or equivalently, the gains from stabilization - will be substantial (Barlevy, 2004).

Regarding the role of fiscal policy, Fatas and Mihov (2003) suggest introducing fiscal rules as a means to reduce the use of discretionary fiscal policy, defined as fiscal policy unrelated to the business cycle, based on their finding for a large cross-section of 91 countries that aggressive use of discretionary policy lowers growth by increasing output volatility. The link between discretionary fiscal policy and the volatility of GDP (as well as consumption and investment) is a very robust result even for highly developed countries as shown by Badinger (2008), who considers a sample of 20 OECD countries, using alternative measures of fiscal policy and estimation approaches.

This paper highlights the role of another important element of fiscal policy, namely cyclical fiscal policy. So far, there are hardly studies investigating the effects of fiscal cyclicality on economic growth. One notable exception is Aghion and Marincescu (2008), who consider an (unbalanced) panel of annual data for 19 OECD countries from 1960 to 2007. Regressing growth on alternative cyclicality measures (and standard controls for economic growth regressions), they find a positive effect of the 'countercyclicality' of fiscal policy on economic growth. The policy relevance of such a finding is obvious. In fact, Aghion and Howitt (2006) argue that the lower degree of countercyclicality in European Monetary Union (EMU) countries is one of the reasons for their poor growth performance relative to the UK or the USA in the 1990s. 
The main goal of the present paper is to shed more light on the role of cyclical fiscal policy and its transmission channels, considering both its effect on output volatility, and - in a second step - its effect on economic growth. We also test whether cyclicality affects growth 'directly' apart from its indirect effect through output volatility. Other then previous studies we consider a large cross-section of 88 countries covering the period 1960 to 2004, which is motivated by the use of (de facto) time-invariant variables on the countries' political and institutional characteristics to identify the causal effect of (endogenous) cyclicality on output volatility.

There is growing evidence that economic policy is shaped to a considerable extent by the characteristics of political and electoral systems (Person and Tabellini, 2000). The use of institutional variables as instruments for fiscal policy was first suggested by Fatas and Mihov (2003) in their study of the effects of discretionary fiscal policy, defined as fiscal policy unrelated to the business cycle, on volatility and economic growth. The present study is closely related to their approach but goes beyond the previous literature by considering the role of cyclical fiscal policy (as well as discretionary fiscal policy). We demonstrate that institutional variables (such political of constraints and the average number of elections) provide considerable information on the variation in fiscal cyclicality across countries, and we use this exogenous variation to identify the causal effect of cyclicality on output volatility and economic growth. We also suggest a new instrument for output volatility, which is based on volatility spillovers from other countries and thus entirely unrelated to a particular country's institutions or policies, in order to explore the robustness of the link between volatility and economic growth.

We find that cyclical fiscal (expenditure) policy has a destabilizing effect on the economy, no matter whether it is pro- or countercyclical. In fact, it amplifies output volatility much the same way as discretionary fiscal policy. This adds to the widespread scepticism against the usefulness of fiscal policy as a fine-tuning instrument. We also find that output volatility, due to variations in cyclical or fiscal policy, negatively affects economic growth. Taken together this has an important policy implication: Economic growth could be enhanced by introducing fiscal rules, designed to restrict both the use of discretionary fiscal policy (Fatas and Mihov, 2003) as well as the use of cyclical fiscal policy.

The remainder of the paper is organized as follows. Section II constructs measures of fiscal cyclicality and the aggressiveness of discretionary fiscal policy for a large cross-section of 88 countries. Section III motivates the identification strategy and provides evidence on the relation between cyclical (and discretionary) fiscal policy and output volatility. Section IV considers the effect of cyclicality on economic growth. Section V summarizes the results and concludes. 


\section{Constructing Measures of Cyclical and Discretionary Fiscal Policy}

Changes in a government's fiscal stance can be decomposed into three components (Gali and Perotti, 2003): i) automatic fiscal responses under the set of existing fiscal rules and institutions, i.e., that part of fiscal policy driven by forces which are largely outside the control of fiscal authorities (at least in the short-run); ii) fiscal policy in response to the business cycle (henceforth 'cyclical fiscal policy'); and iii) fiscal policy unrelated to the business cycle (henceforth 'discretionary fiscal policy'). Although cyclical policy (ii) is also part of discretionary fiscal policy in a broader sense, we reserve the term 'discretionary' exclusively to denote policy unrelated to the cycle throughout this paper.

We use government consumption as indicator of fiscal policy. This choice is dictated by data availability, since there are no internationally comparably data for other measures of fiscal policy for our large cross-section of countries. On the one hand, this limits the generality of our results. On the other hand, an advantage is that government expenditures compared with revenues - are less responsive to the cycle through stabilizers 'built-in' the fiscal system and can be changed with relative ease. As a consequence, expenditures are more indicative of a government's intentional cyclical policy than revenues, whose cyclical behaviour is driven by automatic stabilizers to a much larger extent. And while government consumption is only a subset of total expenditures, results of previous studies suggest that the cyclicality of government consumption reflects the cyclicality of overall government expenditures reasonably well. ${ }^{1}$

We follow the standard approach in the literature and estimate cyclicality parameters $(\chi)$ by regressing growth of real government consumption $(G)$ on the growth of real GDP $(Y)$, correcting for serial correlation in the error term:

$$
\begin{aligned}
& \Delta \ln G_{i, t}=\alpha_{i}+\chi_{i} \Delta \ln Y_{i, t}+\eta_{i, t}, \\
& \eta_{i, t}=\rho_{i} \eta_{i, t-1}+\varepsilon_{i, t} .
\end{aligned}
$$

Equation (1) is estimated separately for each of the $i=1, \ldots, 88$ countries, which is the largest set of countries for which the key variables required in the present study are available. The time dimension $t$ ranges from 1960 to 2004; for some countries, a slightly shorter time span had to be used. Appendix A1 provides a detailed description of the sample and data used.

Equation (1) should be regarded as reduced form equation for government consumption. As Lane (2003) points out there is no reason to control for simultaneous feedback from government spending to GDP. Hence, we estimate equation (1) by ordinary least squares. As

\footnotetext{
In Lane (2003), for example, who studies the determinants of cyclical fiscal policy using a sample of 22 OECD countries, the correlation between the cyclicality of government consumption and that of total government expenditures is 0.71 .
} 
a result we obtain a decomposition of the growth of government consumption into a cyclical and a discretionary component. The time series of country i's cyclical fiscal policy is given by $\hat{\chi}_{i} \Delta \ln Y_{i, t}$; and the estimate of the (structural) residual of equation (1), i.e., $\hat{\varepsilon}_{i, t}$, is interpreted as series of discretionary fiscal policy shocks. By least squares algebra these two series are orthogonal.

As will be outlined more in detail below, the approach pursued here is to identify the effects of cyclical fiscal policy on volatility and growth using the cross-country variation in the data and exploiting the exogeneity of (de facto) time-invariant measures of political and institutional characteristics. Hence, we require country-specific indicators of the average cyclicality of fiscal policy over the time period considered. That is exactly what the estimates of the parameter $\chi_{i}$ measure, a positive (negative) value being associated with procyclical (countercyclical) fiscal behaviour. Our results indicate substantial cross-country variation in the cyclicality parameters, whose estimates range from -0.835 to 2.698. Most of the countries show procyclical fiscal expenditure policy; only 11 of the 88 coefficients are negative. The country-specific cyclicality coefficients $\hat{\chi}_{i, t}$ are reported in Appendix A1.

Regarding discretionary fiscal policy, Fatas and Mihov (2003) interpret the volatility of the error term $\left(\varepsilon_{i, t}\right)$ in an equation similar to (1) over a certain time period as an indicator of a government's aggressiveness of discretionary fiscal policy. In line with this reasoning, we define our empirical measure of discretionary fiscal policy (DISCR) as standard deviation of the residuals from equation (1), i.e., $D I S C R_{i}=\operatorname{sd}\left(\hat{\varepsilon}_{i}\right)$. The country-specific estimates of DISCR are reported in Appendix A1.

Regarding the relevance of cyclical versus discretionary fiscal policy, the $R^{2}$ in equation (1), averaged over all 88 countries, amounts to 0.201 . This means that roughly one-fifth of the total variation in fiscal policy is due to cyclical fiscal policy. This is a non-negligible portion, bearing in mind that the overall variation in government consumption will also partly reflect measurement errors.

Our estimates are well in line with previous studies. Comparing our cyclicality coefficients $\hat{\chi}_{i}$ (for period 1960 to 2004) with those of Lane (2003) for 22 OECD countries (for 1960 to 1998), the correlation is 0.872 . Our measure of discretionary fiscal policy is very close to that of Fatas and Mihov (for 1960 to 2000): The correlation of their levels (logs) is 0.887 (0.945). We conclude that the simple approach given by equation (1) yields reliable estimates of the cross-country variation in discretionary and cyclical fiscal policy, which are comparable with previous studies of fiscal policy. 


\section{Cyclicality of Fiscal Policy and Output Volatility}

\section{The Empirical Model}

Our basic empirical framework is closely related to that of Fatas and Mihov (2003); the novel feature is that the cyclicality of fiscal policy is included as explanatory variable for output volatility:

$$
\ln \sigma_{i}^{y}=\gamma_{0}+\gamma_{1} \ln C Y C_{i}+\mathbf{x}_{i} \gamma+u_{i}
$$

The dependent variable is output volatility $\left(\sigma^{y}\right)$, defined as standard deviation of the growth rate of (real) output per capita; $C Y C$ is our measure of the cyclicality of fiscal policy, which we construct from the estimates of equation (1) as will be outlined more in detail below; $\mathbf{x}_{i}$ is a vector of control variables, and $u$ is a stochastic error term. The cross-section dimension (i) comprises 88 countries, the largest sample for which the required data are available. Unless mentioned otherwise, all data are averages over the period 1960 to 2004. (See Appendix A1 for a more detailed description of the sample and the data.)

As it is standard in skedastic regressions, we choose a logarithmic specification to avoid negative predicted values for the standard deviation of output growth. It is then natural to use the cyclicality measure in log from as well, such that the parameter of our main interest $\left(\gamma_{1}\right)$ measures the relative change of output volatility with respect to relative changes in cyclicality. While the logarithmic specification yields a slightly better fit, it is not crucial for the results, as we show in the sensitivity analysis below.

We define cyclicality (CYC) as absolute value of $\hat{\chi}$ to allow for negative values of the cyclicality coefficients $\hat{\chi}_{i}$ in the logarithmic specification (2a). Obviously, the variable CYC $=|\hat{\chi}|$ then measures only the responsiveness of fiscal policy, but not its direction, i.e., whether it is pro- or countercyclical. This could be addressed by properly signing $\ln C Y C$ for the respective observations. But this would impose the symmetry assumption that - if procyclical policy amplifies business cycles - countercyclical policy smoothes business cycles. This is an assumption we wish to test rather than impose right from the beginning in light of the widespread scepticism against the effectiveness of fiscal policy as fine-tuning instrument. Countercyclical fiscal policy might actually turn out destabilizing due to lags in recognition, implementation, and materialization, a point prominently made by Friedman (1953).

Consequently, we do not impose any assumption about the relation between the effects of pro- and countercyclical policy right from the beginning. Instead, we define $C Y C_{i}$ as absolute value of $\hat{\chi}_{i}\left(C Y C_{i}=\left|\hat{\chi}_{i}\right|\right)$ and allow for different parameters of $\ln C Y C_{i}$, depending on whether $\hat{\chi}_{i}$ is positive or negative for the respective observation $i$ : 


$$
\ln \sigma_{i}^{y}=\gamma_{0}+\gamma_{1} \ln C Y C_{i}+\gamma_{1}^{\text {counter }} D_{i}^{\text {counter }} \ln C Y C_{i}+\mathbf{x}_{i} \gamma+u_{i}
$$

where $D^{\text {counter }}$ is a dummy variable taking a value of 1 for 'countercyclical observations', i.e., $D_{i}^{\text {counter }}=1$ for all $i$ where $\hat{\chi}_{i}<0$ and 0 otherwise. The parameter $\gamma_{1}^{\text {counter }}$ then measures the difference between the effect of countercyclical fiscal policy and the effect of procyclical fiscal policy on output volatility $\left(\gamma_{1}\right)$.

We start from a simple regression of output volatility on cyclicality (CYC) and then add three further explanatory variables: Government size (GSIZE) is included to account for the potentially stabilizing role of larger governments (Gali, 1994). Openness (OPEN), measured as imports plus exports as a share of GDP, is a standard explanatory control for output volatility and fiscal policy according to Rodrik (1998). Finally, the level of development, measured as (log of) real GDP per capita (GDPPC) accounts for the fact that poor countries typically have more volatile business cycles and controls for the quality of institutions and economic policy. Hence, the vector $\mathbf{x}_{\mathrm{i}}=\left[G S I Z E_{i}, O P E N_{i}\right.$, $\left.\ln G D P P C_{i}\right]$. Regarding government size, it has been argued that more volatile economies may have an incentive to set up larger governments as a means to reduce macroeconomic volatility (Rodrik, 1998). As a consequence, GSIZE might be endogenous in equation (2). In line with Fatas and Mihov (2003) we use the standard approach and instrument GSIZE by the (log of) population (POP), the urbanization rate (URBAN), and the dependency ratio (DEP).

In a final step, we will include the aggressiveness of discretionary fiscal policy as defined in section II (DISCR), yielding our most comprehensive model:

$$
\ln \sigma_{i}^{y}=\gamma_{0}+\gamma_{1} \ln C Y C_{i}+\gamma_{2} \ln D I S C R_{i}+\mathbf{x}_{i} \gamma+u_{i}
$$

Before turning to the estimation results for models (2) and (3), two issues warrant discussion. First, our variable of main interest, the cyclicality of fiscal policy (CYC), is endogenous with respect to output volatility as a result of reverse causality. From a theoretical perspective, Talvi and Vegh (2005) show in a political economy model that lobbying for higher public spending during a boom generates a procyclical bias in fiscal policy. A feature of this model is that the larger the incipient primary surplus (the larger the boom) the higher the spending pressures and the resulting political distortions. As a consequence high output volatility tends to generate procyclical fiscal behaviour. ${ }^{2}$ This would introduce an upward bias in the estimated effect of cyclicality on output volatility. In addition, it should be borne in mind that the cyclicality measure $(C Y C)$ is an estimate of its true value. As a result it might be subject to classical measurement error, causing an attenuation bias.

\footnotetext{
${ }^{2}$ Talvi and Vegh (2005) also provide evidence from a large cross-section of countries that the degree of procyclicality in government consumption is positively correlated with output volatility. Lane (2003) obtains a similar results for a sample of 22 OECD countries.
} 
Another issue, related to the fact that our country-specific cyclicality measures $\left(\chi_{i}\right)$ are generated by model (1), is that the observations on our variable $C Y C_{i}$ are estimated with different precision. This is addressed by using a weighted (two stages) least squares procedure, using the inverse of the variance of $\hat{\chi}_{i}$ as weights. ${ }^{3}$ This implies that observations, for which the variable $C Y C$ is measured more precisely, are assigned a higher weight in the regression. As we show below the weighting improves the fit but it is not crucial for the results.

\section{Identification, First Stage Regressions, and Instrument Quality: Political and Institutional Characteristics as Determinants of Cyclicality}

In order to identify the causal effect of cyclicality on output volatility, we use variables on political and institutional characteristics as instruments. This choice is motivated by the growing theoretical literature and empirical evidence that economic policy is as shaped to a considerable extent by the characteristics of political and electoral systems (Person and Tabellini, 2000). At the same time, institutions can be reasonably assumed to be exogenous with respect to output volatility. Fatas and Mihov (2003) were the first to suggest using institutional variables as instruments for (discretionary) fiscal policy.

We hypothesize and demonstrate that countries' political and institutional characteristics are not only relevant determinants of discretionary fiscal policy but also of cyclical fiscal policy. In particular, we consider four institutional variables: i) the average number of elections (NELEC) ii) a measure of political constraints (POLCON) by Henisz (2000), which captures the extent to which the executive faces political constraints to policy implementation; ${ }^{4}$ iii) a dummy for majoritarian systems (MAJ), and iv) a dummy for presidential regimes (PRES).

Notice that the variable $C Y C$, defined as absolute value of cyclicality $(C Y C=|\hat{\chi}|)$, in the first place measures the aggressiveness (but not the direction) of cyclical fiscal policy. As a consequence, part of the discussion by Fatas and Mihov (2003) motivating the use of the institutional variables (NELEC, POLCON, MAJ, PRES) as instruments for the aggressiveness of discretionary policy directly carries over to our measure of cyclical fiscal policy (CYC).

\footnotetext{
${ }^{3}$ The choice of the weight is not affected by the logarithmic transformation. By the delta method, $\sigma_{\ln C Y C}^{2}=1 / \mu_{C Y C} \sigma_{C Y C}^{2}$, i.e. the variances of the level and log of $C Y C$ are equal up to a rescaling by the mean of $C Y C\left(\mu_{C Y C}\right)$.

${ }^{4}$ This $(0,1)$-index counts the number of veto points in the political system and the distribution of preferences across and within the different branches of the government. Power is more dispersed, the greater the number of veto points and the greater the division of control across different political parties (see Henisz (2000) for more details).
} 
The extent of political constraints $(P O L C O N)$ is the instrument with the strongest theoretical motivation. According to the 'voracity hypothesis' (Tornell and Lane, 1998), power diffusion among more agents induces procyclicality, since fiscal competition by multiple power groups for fiscal revenues increases (decreases) in booms (recessions). On the other hand, governments less constrained in implementing their policy can respond more flexibly to the business cycle and will thus be better able to translate their 'cyclicality preferences' into actual policy. What we observe is only the net outcome; this bottom line effect of $P O L C O N$ is ambiguous and remains to be determined empirically.

Regarding the electoral characteristics, there is a tradeoff between election-related and cyclical fiscal policy. The frequency and timing of elections (NELEC) and the induced electoral cycles will not be systematically related to the business cycle in general. As a consequence, the observed pattern of fiscal policy will show a smaller association with the (business) cycle, the larger the number of elections, i.e., the more the relation of fiscal policy to the business cycle is diluted by fiscal policy measures associated with the electoral cycle. A similar point can be made for MAJ in light of the argument by Persson and Tabellini (2001) that majoritarian systems will have more pronounced electoral cycles.

Regarding the dummy for presidential regimes (PRES), it is less clear whether one would expect a relationship with cyclicality. It could be the case that presidential regimes will not only be associated with a more aggressive use of discretionary fiscal policy as argued by Fatas and Mihov (2003), but also with a more active conduct of cyclical fiscal policy.

While our choice of institutional variables as instruments for cyclicality is well motivated theoretically, the ultimate question is whether the variables NELEC, POLCON, $M A J$, and PRES are also relevant instruments in our empirical model, i.e., whether they are informative about the variation in fiscal cyclicality in our sample of countries. Table 1 reports the results of a regression of the log of $C Y C$ on the four institutional variables separately (columns (1a) to (1d)) and simultaneously (column (2a)). The number of elections (NELEC) and political constraints (POLCON) turn out to have the strongest effect; they are significant both in a simple regression (columns (1a) and (1b)) and in a multiple regression on all four political variables (column (2a)). The sign of the coefficient of NELEC is negative as expected. The variable POLCON also enters with a negative sign; this does not necessarily reject the voracity hypothesis but suggests that - among the various ways through which political constraints affect the cyclicality of fiscal (expenditure) policy - the voracity effect does not appear to be the most dominant force. ${ }^{5}$ The variables MAJ and PRES are insignificant or only weakly significantly in a simple regression (columns (1c) and (1d)); in a multiple regression on all four institutional variables, both MAJ and PRES turn out

\footnotetext{
Lane (2003) also finds little support for the voracity hypothesis in his study of the cyclicality of expenditures in a sample of 22 OECD countries; in particular, the effect of political constraints on cyclicality is often insignificant or shows the wrong sign.
} 
insignificant with p-values of 0.854 and 0.789. Since the variables MAJ and PRES are uninformative about fiscal cyclicality, their inclusion in the first stage regression would only weaken the quality of our set of instruments (compare the F-statistic in columns (2a) and (2b)). Consequently, we will use only NELEC and POLCON as instruments for CYC in the two stages least squares regressions below.

Table 1. Political Determinants of Cyclicality and First Stage Regressions

\begin{tabular}{|c|c|c|c|c|c|c|c|c|}
\hline $\begin{array}{l}\text { Dependent } \\
\text { variable is: }\end{array}$ & $\begin{array}{c}(1 \mathrm{a}) \\
\ln C Y C\end{array}$ & $\begin{array}{c}(1 \mathrm{~b}) \\
\ln C Y C\end{array}$ & $\begin{array}{c}(1 \mathrm{c}) \\
\ln C Y C\end{array}$ & $\begin{array}{c}(1 \mathrm{~d}) \\
\ln C Y C\end{array}$ & $\begin{array}{c}(2 \mathrm{a}) \\
\ln C Y C\end{array}$ & $\begin{array}{c}(2 \mathrm{~b}) \\
\ln C Y C\end{array}$ & $\begin{array}{c}(3) \\
\ln C Y C\end{array}$ & $\begin{array}{c}(4) \\
\ln \sigma^{D i s c r}\end{array}$ \\
\hline NELEC & $\begin{array}{l}-2.674^{* * *} \\
(0.774)\end{array}$ & & & & $\begin{array}{l}-2.566^{* *} \\
(1.000)\end{array}$ & $\begin{array}{l}-2.391^{* * *} \\
(0.660)\end{array}$ & $\begin{array}{l}-2.305^{* * *} \\
(0.767)\end{array}$ & $\begin{array}{l}-0.513 \\
(0.355)\end{array}$ \\
\hline POLCON & & $\begin{array}{l}-1.905^{* * *} \\
(0.334)\end{array}$ & & & $\begin{array}{l}-1.704^{* * *} \\
(0.569)\end{array}$ & $\begin{array}{l}-1.822^{* * *} \\
(0.313)\end{array}$ & $\begin{array}{l}-1.489^{* *} \\
(0.658)\end{array}$ & $\begin{array}{l}-0.470^{* *} \\
(0.236)\end{array}$ \\
\hline$M A J$ & & & $\begin{array}{l}-0.007 \\
(0.233)\end{array}$ & & $\begin{array}{l}0.036 \\
(0.197)\end{array}$ & & & $\begin{array}{l}0.139^{* *} \\
(0.068)\end{array}$ \\
\hline PRES & & & & $\begin{array}{l}0.460^{*} \\
(0.242)\end{array}$ & $\begin{array}{l}0.112 \\
(0.415)\end{array}$ & & & $\begin{array}{l}0.408^{* * *} \\
(0.143)\end{array}$ \\
\hline $\ln P O P$ & & & & & & & $\begin{array}{l}-0.196^{* * *} \\
(0.064)\end{array}$ & $\begin{array}{l}-0.082^{* *} \\
(0.024)\end{array}$ \\
\hline$U R B A N$ & & & & & & & $\begin{array}{l}-0.800 \\
(0.753)\end{array}$ & $\begin{array}{l}0.004 \\
(0.259)\end{array}$ \\
\hline$D E P$ & & & & & & & $\begin{array}{l}3.003^{*} \\
(1.549)\end{array}$ & $\begin{array}{l}0.477 \\
(0.568)\end{array}$ \\
\hline OPEN & & & & & & & $\begin{array}{l}-0.577^{* *} \\
(0.299)\end{array}$ & $\begin{array}{l}0.091 \\
(0.102)\end{array}$ \\
\hline $\ln G D P P C$ & & & & & & & $\begin{array}{l}0.609^{*} \\
(0.359)\end{array}$ & $\begin{array}{l}-0.283^{* *} \\
(0.122)\end{array}$ \\
\hline F-stat. ${ }^{1)}$ & $11.934^{* * *}$ & $32.589^{* * *}$ & 0.001 & $3.594^{*}$ & $12.312^{* * *}$ & $25.142^{* * * *}$ & $6.587^{* *}$ & $6.289^{* * *}$ \\
\hline F-stat. ${ }^{2)}$ & & & & & & & $8.472^{* * *}$ & $8.663^{* * *}$ \\
\hline$R^{2}$ & 0.122 & 0.275 & 0.000 & 0.040 & 0.372 & 0.372 & 0.502 & 0.872 \\
\hline Observations & 88 & 88 & 88 & 88 & 88 & 88 & 88 & 88 \\
\hline
\end{tabular}

Notes: A constant is included in all models. ${ }^{*},{ }^{* *},{ }^{* * *}$ denote significance at 10,5 , and 1 percent level respectively; standard errors in parenthesis. Table reports weighted least squares estimates, using the inverse of the variance of $C Y C$ as weight. $R^{2}$ refers to weighted model. ${ }^{1)}$ F-test on excluding the institutional variables (NELEC, POLCON, MAJ, PRES) from first stage regression for $\ln C Y C$ and $\ln \sigma^{\text {Discr }}{ }^{2)}$ F-Test on excluding all instruments (institutional variables, $\ln P O P, U R B A N, D E P$ ) from regression.

Notice that column (2b) corresponds to the first stage regression for equation (2a) only in the most parsimonious specification without additional explanatory variables for output volatility. In the extended models, a more relevant issue is the partial correlation of NELEC 
and POLCON with CYC, controlling for the other explanatory variables (GSIZE, OPEN, and $G D P P C$ ). The first stage regression for the most comprehensive model including all controls - GSIZE (instrumented by POP, URBAN, and DEP), OPEN, and GDPPC - is given in column (3). An important result is that the variables NELEC and POLCON remain significant, both individually and jointly.

Column (4) shows the corresponding first stage regression for discretionary fiscal policy (DISCR). Results are in line with Fatas and Mihov (2003). Notice that - in contrast to the first stage regression for $C Y C$ - the two variables MAJ and PRES turn out significant at the five and one percent level. At least from an empirical perspective, this suggest that the variation in the variables $M A J$ and PRES can help to identify the (separate) effect of discretionary policy in model (3), where both CYC and DISCR are included simultaneously.

Overall, the results reveal interesting links between institutions and cyclicality. Exploring these links more in detail is beyond the scope of this paper. For the purpose of the present study, the most relevant message from the results in Table 2 is that the two variables NELEC and POLCON are relevant instruments for cyclicality (CYC); this is not the case for the variables $M A J$ and $P R E S$, which are, however, strongly associated with the aggressiveness of discretionary fiscal policy (DISCR).

\section{Estimation Results}

We start from the most parsimonious specification of model (2), which includes only cyclicality $(C Y C)$ as explanatory variable. ${ }^{6}$ Columns (1a) and (1b) show the weighted least squares estimates (WLS) of equation (2a), which allows the effects of pro- and countercyclical fiscal policy to differ by including an interaction between CYC and a dummy for countercyclical policy ( $D^{\text {counter }}$ ). The estimated elasticity of output volatility with respect to procyclical fiscal policy is 0.184 ; the effect of countercyclical policy appears to be even larger (0.278), but the difference is insignificant with a p-value of 0.300 . This conclusion holds up when the model is estimated by weighted two stages least squares (WTSLS), using the average number of elections (NELEC) and the index of political constraints (POLCON) as instruments for CYC (column (1b)). In that case the elasticities with respect to pro- and countercyclical fiscal policy are 0.595 and 0.501 respectively, but again the difference is insignificant (p-value: 0.618).

Table 2. Cyclicality of Fiscal Policy and Output Volatility - Basic Model

\footnotetext{
${ }^{6}$ The weighting accounts for the fact that $C Y C$ is a generated regressor, not for the presence of heteroskedasticity in the error term in models (2) or (3) (which is also confirmed by standard tests). Hence, we use robust standard errors for inference throughout.

${ }^{7}$ We add that in a specification with two variables included, one for procyclical policy $\left(\left(1-D^{\text {counter }}\right) C Y C\right)$ and one for countercyclical policy $\left(D^{\text {counter }} C Y C\right)$, both coefficients are individually significant at the one percent level as well. Of course, the implied coefficients and the test for parameter equality are identical to the specification considered in column (1b) in Table 2.
} 


\begin{tabular}{|c|c|c|c|c|c|c|c|c|}
\hline & (1a) & (1b) & (2a) & $(2 b)$ & (3a) & (3b) & (4a) & (4b) \\
\hline & WLS & WTSLS & WLS & WTSLS & LS & TSLS & WTSLS & WTSLS \\
\hline $\ln C Y C$ & $\begin{array}{l}0.184^{* *} \\
(0.082)\end{array}$ & $\begin{array}{l}0.595^{* *} \\
(0.232)\end{array}$ & $\begin{array}{l}0.239^{* * *} \\
(0.060)\end{array}$ & $\begin{array}{l}0.600^{* * *} \\
(0.207)\end{array}$ & $\begin{array}{l}0.150^{* * *} \\
(0.044)\end{array}$ & $\begin{array}{l}0.742^{* * *} \\
(0.185)\end{array}$ & & \\
\hline$D^{\text {counter }} \ln C Y C$ & $\begin{array}{l}0.094 \\
(0.083)\end{array}$ & $\begin{array}{l}-0.094 \\
(0.208)\end{array}$ & & & & & & \\
\hline CYC & & & & & & & $\begin{array}{l}1.432^{* * *} \\
(0.311)\end{array}$ & $\begin{array}{l}1.762^{* * *} \\
(0.332)\end{array}$ \\
\hline$D^{\text {counter }} C Y C$ & & & & & & & $\begin{array}{l}-0.528 \\
(0.517)\end{array}$ & \\
\hline Hausman $^{1)}$ (p-val.) & & $(0.000)$ & & $(0.000)$ & & $(0.000)$ & $(0.000)$ & $(0.000)$ \\
\hline OID $^{2)}$ (p-val.) & & $(0.128)$ & & $(0.236)$ & & $(0.227)$ & $(0.036)$ & $(0.887)$ \\
\hline$R^{2}$ & 0.128 & 0.096 & 0.108 & 0.108 & 0.108 & 0.108 & 0.105 & 0.099 \\
\hline SEE & 0.448 & 0.606 & 0.454 & 0.626 & 0.431 & 0.731 & 0.768 & 0.915 \\
\hline Observations & 88 & 88 & 88 & 88 & 88 & 88 & 88 & 88 \\
\hline
\end{tabular}

Notes: Dependent variable is $\ln \sigma^{y}$. A constant is included in all models. ${ }^{*}{ }^{* * *},{ }^{* * *}$ denote significance at 10, 5, and 1 percent level respectively; robust standard errors in parenthesis. WLS denotes weighted least squares estimates, using the inverse of the variance of CYC as weight. (W)TSLS denotes (weighted) two stages least squares, using NELEC and POLCON as instruments for CYC. $R^{2}$ refers to unweighted model, calculated as squared correlation between actual and predicted values. ${ }^{1)}$ Heteroskedasticity-robust test for exogeneity; $\mathrm{H}_{0}$ : CYC is exogenous. ${ }^{2)}$ Heteroskedasticity-robust test of overidentifying restrictions; $\mathrm{H}_{0}: N E L E C, P O L C O N$ are valid instruments.

In light of this result it appears to be justified to proceed with a restricted model, imposing parameter equality for pro- and countercyclical fiscal policy. Columns (2a) and (2b) show the WLS and WTSLS estimates of the simple regression of volatility on cyclicality. For comparison, columns (3a) and (3b) show the results of the unweighted LS and TSLS estimates. Notice first, that endogeneity of CYC is indeed pronounced: The difference between the (W)LS and (W)TSLS coefficients is sizeable. More formally, a Hausman test rejects that $C Y C$ is exogenous at the one percent level in all specifications. It is interesting to note that both the weighted and unweighted LS estimates of the effect of CYC on volatility show a strong attenuation bias towards zero. This suggests that measurement error is the dominant source of endogeneity rather than reverse causality (causing an upward bias). This view is also supported by a comparison of the weighted and unweighted estimates. In the weighted regressions, less precise estimates are assigned a lower weight, rendering the role of measurement error less relevant. As a consequence, the attenuation bias is less pronounced in the WLS regression, yielding coefficients that are closer to the WTSLS estimates.

While we postpone a more comprehensive sensitivity analysis to below, we emphasize that the weighting is not crucial for the results: A comparison of columns (2b) and (3b) shows that the weighted and unweighted TSLS estimates are virtually identical, pointing to an 
elasticity of output volatility with respect to cyclicality of around 0.6. The choice of the logarithmic form of $C Y C$ is not essential for the qualitative conclusions as well: The corresponding results for the specification in levels (columns (4a) and (4b)) are in line with the logarithmic specification (columns (1b) and (2b)).

A final observation is that the tests for overidentifying restrictions reject the null hypothesis of valid instruments in some specifications. This is not too surprising, given that several important variables have been omitted from the regression so far. Results for a more comprehensive model, including GSIZE, OPEN and GDPPC as controls are given in Table 3. As already discussed above, government size is likely to be endogenous with respect to volatility, which is addressed by using population (POP), the urbanization rate (URBAN), and the dependency ratio (DEP) as instruments for GSIZE.

Columns (1a) and (1b) show the unweighted LS and TSLS estimates, whereas column (1c) gives the results of the WTSLS estimation. As expected the estimated elasticity of volatility with respect to cyclicality becomes smaller in magnitude when the control variables are added (around 0.3) but remains significant. Exogeneity of CYC is still clearly rejected in all models; we thus focus on the (W)TSLS results. The OID tests are insignificant in most specifications, suggesting that the institutional variables NELEC and POLCON (as well as $P O P, D E P, U R B A N)$ are valid instruments. To reinforce the finding of our parsimonious specification, we repeat the test for parameter equality between pro- and countercyclical policy (see columns (2a) and (2b)). The conclusion is the same as before: There is no evidence for a stabilizing effect of countercyclical fiscal policy. In contrast, it adds to output volatility, in a way not significantly different from that of procyclical fiscal policy.

Of course, the results regarding the role of countercyclical policy should be interpreted with care. The number of countries which pursued countercyclical fiscal policy on average is rather small (11 out of the 88). While this might be too little variation to yield a significant difference in the estimated effect, it does not explain that the effect of countercyclical policy on volatility is always positive, a finding that is extremely robust. We also emphasize that our results should be interpreted as averages over countries and time. One cannot rule out that a highly effective government, which is aware of the relevant lag structures and able to respond very quickly, might be successful in its fiscal efforts to smooth business cycles. What our evidence suggest, however, is that such a constellation is rather the exception than the rule. 
Table 3. Cyclicality of Fiscal Policy and Output Volatility - Extended Model

\begin{tabular}{|c|c|c|c|c|c|c|c|c|}
\hline & $\begin{array}{l}\text { (1a) } \\
\text { LS }\end{array}$ & $\begin{array}{l}\text { (1b) } \\
\text { TSLS }\end{array}$ & $\begin{array}{c}\text { (1c) } \\
\text { WTSLS }\end{array}$ & $\begin{array}{c}(2 \mathrm{a}) \\
\text { TSLS }\end{array}$ & $\begin{array}{c}(2 b) \\
\text { WTSLS }\end{array}$ & $\begin{array}{c}\text { (3a) } \\
\text { WTSLS }\end{array}$ & $\begin{array}{c}(3 b) \\
\text { LIML }\end{array}$ & $\begin{array}{c}(4) \\
\text { WTSLS }\end{array}$ \\
\hline $\ln C Y C$ & $\begin{array}{l}0.079^{*} \\
(0.040)\end{array}$ & $\begin{array}{l}0.676^{* *} \\
(0.270)\end{array}$ & $\begin{array}{l}0.292^{* *} \\
(0.119)\end{array}$ & $\begin{array}{l}0.318^{*} \\
(0.166)\end{array}$ & $\begin{array}{l}0.324^{*} \\
(0.188)\end{array}$ & $\begin{array}{l}0.163^{*} \\
(0.090)\end{array}$ & $\begin{array}{l}0.182^{* *} \\
(0.083)\end{array}$ & $\begin{array}{l}0.238^{* * *} \\
(0.068)\end{array}$ \\
\hline$D^{\text {counter }} \ln C Y C$ & & & & $\begin{array}{l}-0.067 \\
(0.133)\end{array}$ & $\begin{array}{l}-0.084 \\
(0.153)\end{array}$ & & & \\
\hline $\ln D I S C R$ & & & & & & $\begin{array}{l}0.454 \\
(0.276)\end{array}$ & $\begin{array}{l}0.417^{* *} \\
(0.204)\end{array}$ & restricted \\
\hline GSIZE & $\begin{array}{l}-0.045 \\
(0.620)\end{array}$ & $\begin{array}{l}1.840 \\
(4.894)\end{array}$ & $\begin{array}{l}-3.406 \\
(3.903)\end{array}$ & $\begin{array}{l}0.635 \\
(0.260)\end{array}$ & $\begin{array}{l}-6.354 \\
(4.654)\end{array}$ & $\begin{array}{l}-2.709 \\
(2.854)\end{array}$ & $\begin{array}{l}-1.299 \\
(0.994)\end{array}$ & $\begin{array}{l}-3.431 \\
(2.724)\end{array}$ \\
\hline OPEN & $\begin{array}{l}0.176^{* *} \\
(0.080)\end{array}$ & $\begin{array}{l}0.447^{*} \\
(0.257)\end{array}$ & $\begin{array}{l}-0.003 \\
(0.194)\end{array}$ & $\begin{array}{l}0.293^{*} \\
(0.166)\end{array}$ & $\begin{array}{l}0.077 \\
(0.196)\end{array}$ & $\begin{array}{l}-0.118 \\
(0.129)\end{array}$ & $\begin{array}{l}-0.108 \\
(0.109)\end{array}$ & $\begin{array}{l}-0.061 \\
(0.158)\end{array}$ \\
\hline $\ln G D P P C$ & $\begin{array}{l}-0.239^{* * *} \\
(0.041)\end{array}$ & $\begin{array}{l}-0.096 \\
(0.125)\end{array}$ & $\begin{array}{l}-0.206 \\
(0.127)\end{array}$ & $\begin{array}{l}-0.189^{* * *} \\
(0.071)\end{array}$ & $\begin{array}{l}-0.166 \\
(0.158)\end{array}$ & $\begin{array}{l}-0.004 \\
(0.107)\end{array}$ & $\begin{array}{l}-0.013 \\
(0.099)\end{array}$ & $\begin{array}{l}-0.088 \\
(0.114)\end{array}$ \\
\hline Hausman ${ }^{1)}$ (p-val.) & & $(0.000)$ & $(0.000)$ & $(0.179)$ & $(0.000)$ & $(0.016)$ & & $(0.000)$ \\
\hline OID ${ }^{2)}$ (p-val.) & & $(0.893)$ & $(0.683)$ & $(0.057)$ & $(0.554)$ & $(0.817)$ & & $(0.913)$ \\
\hline$R^{2}$ & 0.404 & 0.159 & 0.279 & 0.292 & 0.220 & 0.479 & 0.534 & 0.376 \\
\hline SEE & 0.358 & 0.658 & 0.507 & 0.418 & 0.583 & 0.469 & 0472 & 0.485 \\
\hline Observations & 88 & 88 & 88 & 88 & 88 & 88 & 88 & 88 \\
\hline
\end{tabular}

Notes: Dependent variable is $\ln \sigma^{y}$. A constant is included in all models. ${ }^{*}{ }^{* * *}{ }^{* * *}$ denote significance at 10, 5, and 1 percent level respectively; robust standard errors in parenthesis. WLS denotes weighted least squares estimates, using the inverse of the variance of CYC as weight. (W)TSLS denotes (weighted) two stages least squares, using NELEC and POLCON as instruments for CYC and using NELEC, POLCON, MAJ, and PRES as instruments for CYC and DISCR in columns (3) and (4). ${ }^{1)}$ Heteroskedasticity-robust Hausman test for exogeneity; $\mathrm{H}_{0}$ : $\ln C Y C$, GSIZE (and $\ln$ DISCR) are exogenous. ${ }^{2)}$ Heteroskedasticity-robust test of overidentifying restrictions; $\mathrm{H}_{0}$ : NELEC, POLCON (MAJ, PRES ) and $\ln P O P, D E P, U R B A N$ are valid instruments.

Finally, we consider the results for model (3), which includes both cyclicality (CYC) and discretionary fiscal policy (DISCR). It is a subtle question, whether discretionary fiscal policy should be controlled for. On the one hand, discretionary fiscal policy is certainly a relevant determinant of output volatility (Fatas and Mihov (2003), Badinger (2008)). Moreover, while the time series of discretionary and cyclical fiscal policy measures for a single country are orthogonal, this does not carry over the cross-country variation in cyclical and discretionary policy (averaged over time): Countries that are more responsive to the cycle might also more actively engage in discretionary fiscal policy.

Under these two assumptions - DISCR matters for volatility and is related to CYC - the estimated effect of CYC in model (2) will be upward biased due to the omission of DISCR. In that case, however, we would also expect the OID test to reject instrument validity, since the instruments used for CYC (i.e., POLCON, NELEC) are also related to discretionary policy 
(see section III, subsection 2). But this is not the case in any of the specifications, suggesting that these two elements of fiscal policy could be (close to) orthogonal in the cross-section.

One could still argue that the OID test has small power and CYC and DISCR should be regarded as related for theoretical reasons. Even in that case the question remains, whether discretionary policy should be controlled for: A main reason for a possible association between DISCR and CYC is that an active conduct of cyclical fiscal policy might partly result in (unintentional) discretionary policy (unrelated to the cycle) as a result of lags in implementation and materialization (again, on average over countries and time). Since these unintentional consequences of cyclical fiscal policy can hardly be ruled out by policy makers in practice, it might be reasonable to let the parameter of cyclicality in model (2) also capture its indirect effects on volatility through is relation to discretionary fiscal policy.

Notwithstanding these arguments that might favour model (2) over model (3), we now turn to the results when DISCR is included (see column (3a)). As expected the coefficient of CYC becomes smaller, pointing to an elasticity of volatility with respect to cyclicality of around 0.163 , but it remains significant at the 10 percent level. The elasticity with respect to discretionary fiscal policy is 0.454 but insignificant with a p-value of 0.103 . This is not too surprising; since both variables are instrumented using mainly the same set of institutional variables (only MAJ and PRES are added as additional instruments for DISCR), the predicted values for CYC and DISCR from the first stage regressions will be strongly correlated, causing a multicollinearity problem in the second stage regression. This is aggravated by the presence of a third endogenous variable (GSIZE). ${ }^{8}$

There are several ways to address this weak instruments problem: The most obvious would be to identify further instruments. Since it is difficult to think of variables affecting cyclicality $(C Y C)$ but not the aggressiveness of discretionary fiscal policy (DISCR) and vice versa, this approach does not appear to be very promising in the present context. Alternatively, an estimation technique more robust to weak instruments could be used. Stock and Yogo (2004), who consider the consequences of weak instruments and the performance of alternative estimators, find that limited information maximum likelihood (LIML) is far superior to TSLS estimation in the presence of weak instruments. Hence, we reestimate model (3) using LIML (see column (3b)): In that case CYC and DISCR turn both out significant with elasticities of 0.182 and 0.417 respectively.

\footnotetext{
${ }^{8}$ If government size is treated exogenous and population is included as instrument, CYC and DISCR turn out significant at the five and one percent level respectively. However, since there are strong theoretical arguments to regard government size as endogenous, and since the theoretical motivation for using country size (population) as instrument for CYC and DISCR is weak (despite the fact that is highly significant in the first stage regression), we pursue the more conservative approach here and treat GSIZE as endogenous.

${ }^{9}$ Note that the superiority of LIML estimation in Stock and Yogo (2004) is obtained under homoscedasticity, which is also assumed in the LIML estimation here.
} 
Another route would be to use a compound measure of discretionary and cyclical fiscal policy ( $\ln C Y C+\ln D I S C R$ ), which could be justified in light of the fact that the hypothesis of parameter equality cannot be rejected (F-statistic: 0.704, p-value: 0.403). Results are given in column (4): In the restricted model, the compound measure of fiscal policy turns out highly significant with a coefficient of 0.238 . The economic interpretation of this restricted model with equal parameters for cyclical and discretionary fiscal policy carries our finding regarding the irrelevance of the direction of cyclicality one step further: Not only has countercyclical policy the same effect on volatility as procyclical fiscal policy. It also implies that cyclical fiscal policy (CYC) has the same amplifying effect on output volatility as 'random' discretionary fiscal policy shocks, suggesting that the effects of intentional cyclical policy measures - due to poor timing and lags in implementation and materialization - spread over time in a way such that the implied average outcome is random with respect to the cycle. ${ }^{10}$ Since the focus of the present paper is on cyclicality, however, we do not use a compound measure of fiscal policy in the following.

\section{Robustness}

We first demonstrate that the logarithmic transformation of $C Y C$ is not crucial for the results. Column (1a) in Table 4 uses the level of CYC and allows for parameter heterogeneity between pro- and countercyclical fiscal policy. As in the logarithmic specification, there is no evidence that countercyclical fiscal policy has a significantly different effect on volatility than procyclical fiscal policy. Column (1b) gives the results, when the parameters of pro- and countercyclical fiscal policy (in levels) are restricted to equality: CYC turns out significant at the 5 percent level with an average elasticity of 0.737 . Judged by the standard error of estimation, the fit is worse than for the specification in log form.

We next consider subsample stability of the results for models (2) and (3) with respect to the country dimension. A visual inspection of a scatter plot of output volatility against cyclicality does not suggest that our results are driven by a few extreme observations (see Figure 1). We nevertheless reestimate models (2) and (3), excluding countries with 'large' output volatility or 'large' cyclicality from the sample.

\footnotetext{
${ }^{10}$ This argument was already made by Friedman in his informal essay on fiscal policy: "In fiscal as in monetary policy, all political considerations aside, we simply do not know enough to be able to use deliberate changes in taxation and or expenditures as a sensitive stabilization mechanism. In the process of trying to do so, we almost surely make matters worse... by introducing a largely random disturbance that is simply added to other disturbances.“(Friedman, 1962, p. 78).
} 
Table 4. Cyclicality of Fiscal Policy and Output Volatility - Robustness

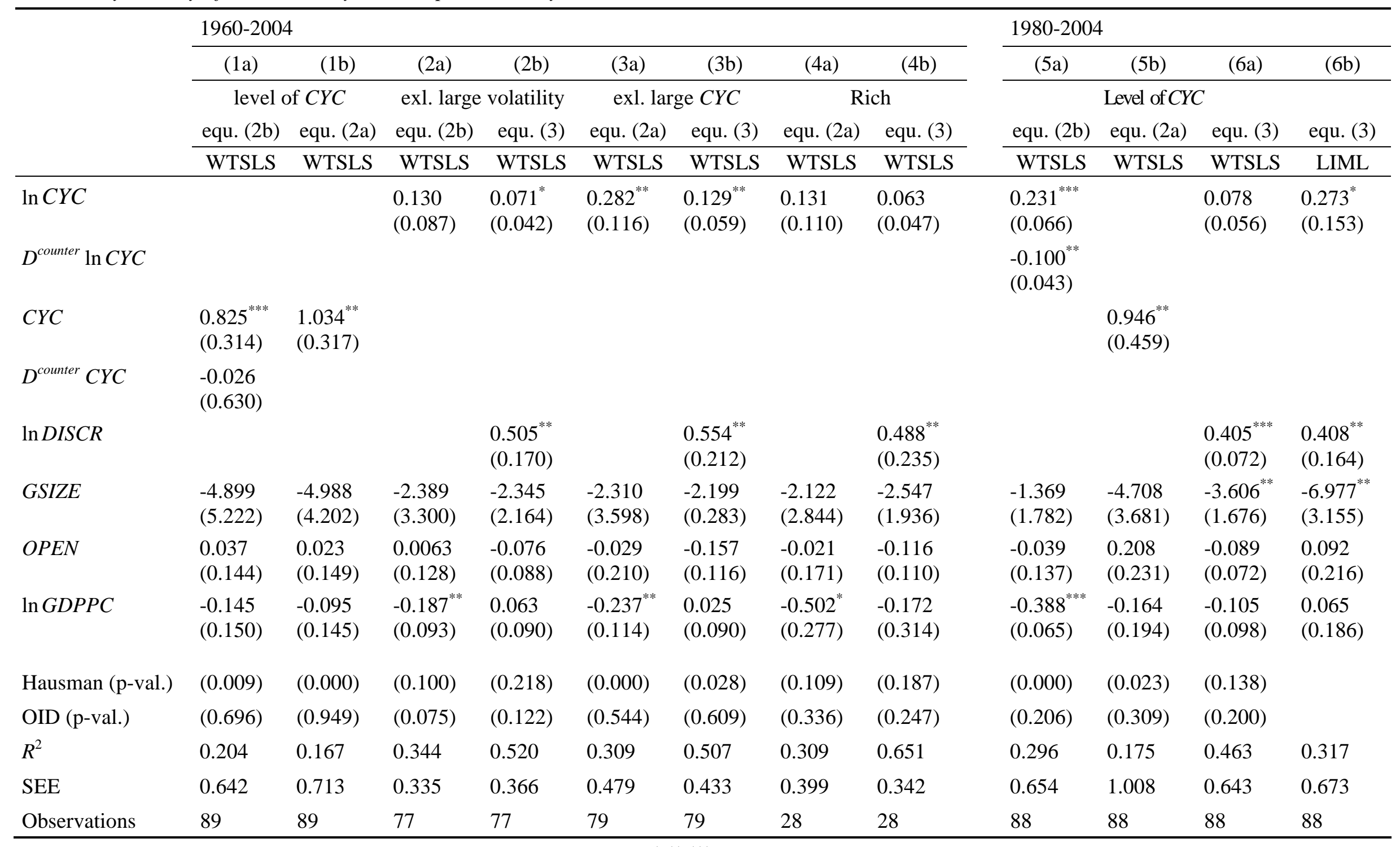

Notes: Dependent variable is $\ln \sigma^{y}$. A constant is included in all models. ${ }^{* * *, * * *}$ denote significance at 10,5 , and 1 percent level respectively; robust standard errors in parenthesis. See also Tables 2 and 3. 


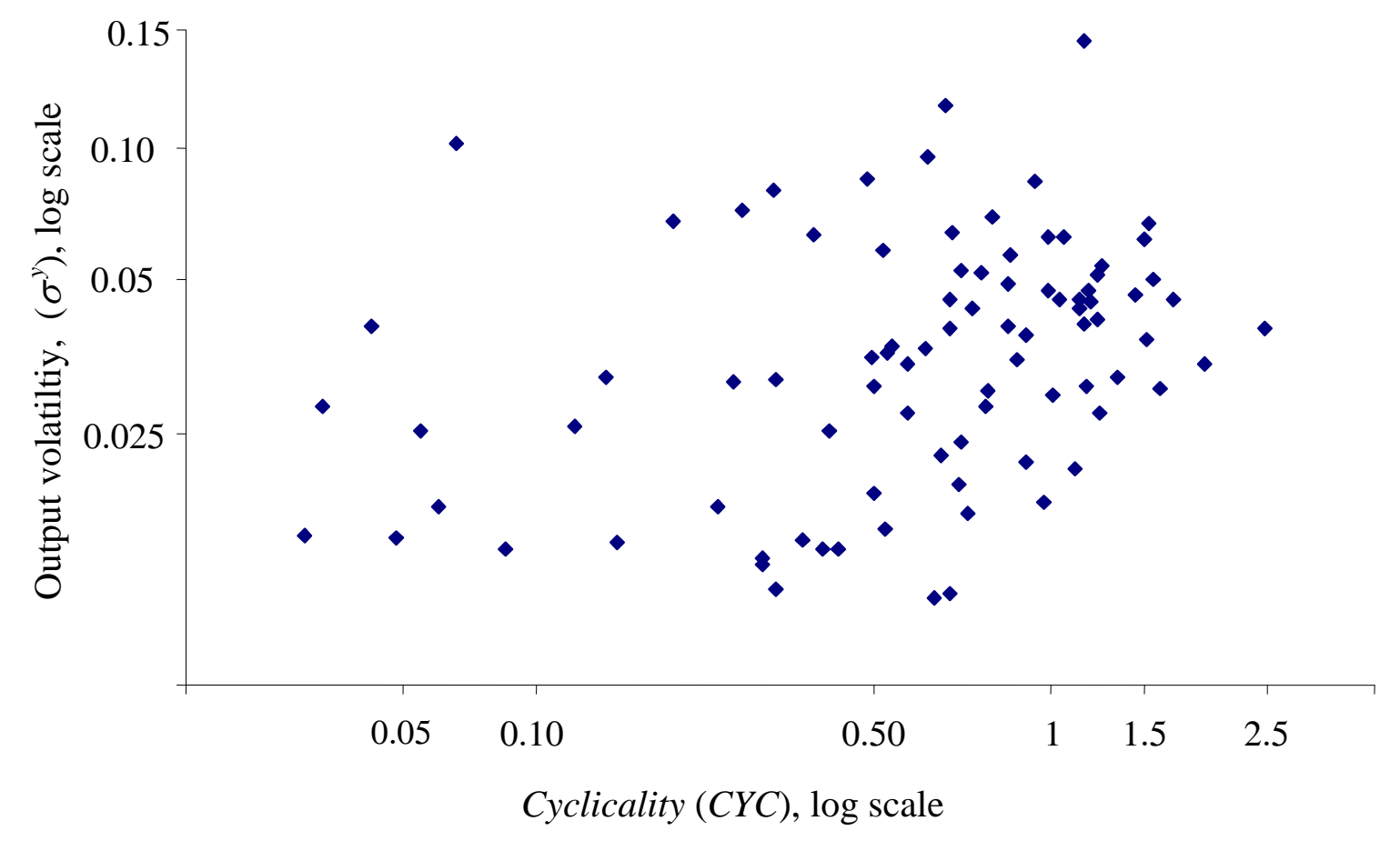

Columns (2a) and (2b) give the results for models (2) and (3), excluding countries whose output volatility exceeds the sample average by more than one standard deviation. The same exercise is repeated in columns (3a) and (3b), excluding countries whose cyclicality coefficients exceed the sample average by more than one standard deviation. Overall, the results for the full sample in Table 2 hold up, confirming that our results are not driven by a few outlying observations.

In columns (4a) and (4b) we focus on a subsample of 28 'rich' countries, constituting the upper third of the income distribution of our sample in terms of GDP per capita. In both models (2) and (3) the variable CYC becomes insignificant with p-values of 0.245 and 0.193 , respectively. However, if the level of development (GDPPC) is excluded, which appears to be justifiable for a group of countries with a similar level of development (in particular in model (3) where GDPPC is insignificant), CYC becomes significant again in models (2) and (3) at the 10 and 5 percent level respectively. Moreover, if the level rather than the log of CYC is used, the variable $C Y C$ is close to significance with a p-value of 0.116 in model (2) (even with GDPPC included). (The qualitative results are essentially the same for the OECD subsample.) It goes without saying that these estimates, relying on asymptotic properties, should not be overstressed due to the small number of observations. Overall, our reading of these results is that in the group of highly developed countries, cyclical fiscal policy appears to have a significant though somewhat less pronounced destabilizing effect.

In a final step we consider the results for the more recent period 1980 to 2004 to rule out that our estimates are driven by the comparably erratic times up the 1980s. We first note that 
our estimates of the cyclicality parameters $(C Y C)$ and the aggressiveness of discretionary fiscal policy (DISCR) for the full period from 1960 to 2004 and for the period of 1980 to 2004 are fairly similar (see Appendix A1). Many of the countries that pursued countercyclical fiscal policy from 1960 to 2004 on average did so as well in the period from 1980 to 2004. The correlation between CYC (DISCR) for the two time periods is 0.766 (0.935). This also favours the interpretation that (de facto) time invariant institutional features of countries have a strong impact on the cross-country variation in the conduct of fiscal policy.

Turning to the estimation results, a slight difference to the period 1960 to 2004 is that the effect of countercyclicality on volatility appears to be significantly different in magnitude from that of procyclical policy in the logarithmic specification (see column (5a)), though its effect on output volatility is still clearly positive. It is tempting to argue that countercyclical policy has become partly more effective (and thus overall less destabilizing). But this appears to be overstressing results a bit, given that there is no significant difference between the effects of pro- and countercyclical policy if the level rather than the log of CYC is used; column (5b) shows the (restricted) model using the level of CYC.

The estimates of model (3) for the period 1980 to 2004 (columns (6a) and (6b)), where DISCR is included along with CYC, are in line with the results for the full period 1960 to 2000, in particular when the model is estimated using limited information maximum likelihood (column (6b)). As before the hypothesis of parameter equality of CYC and DISCR cannot be rejected.

Finally, we add that the subsample stability with respect to the cross-country dimension for the period 1980 to 2004 (excluding countries with large volatility or large cyclicality, or considering rich countries only) is qualitatively very similar to that for the full period.

\section{Fiscal Cyclicality, Volatility, and Economic Growth}

Having established a relationship between cyclicality and output volatility we now go on to assess the effect of cyclicality on economic growth through output volatility. From a theoretical perspective, the relation between output volatility and economic growth is ambiguous. A positive relation is conceivable as a result of a Schumpeterian cleansing effect of recessions (e.g., Caballero and Hammour, 1991) or due to the fact that the opportunity costs of productivity enhancing reorganizations are smaller during recessions (Hall, 1991). A negative relation might result from irreversibilities in investments or from credit market imperfections that constrain productivity enhancing investments in recession (Aghion et al. 2006). The relation between volatility and growth is even more intricate, since causality may also run from growth to volatility (Stiglitz, 1993). Empirically, Ramey and Ramey (1995) found a negative effect of output volatility on economic growth, and - though there is no consensus so far - the evidence that has emerged since then tends to support this finding. 
While a number of studies have considered the effect of output volatility on growth, there is hardly evidence on the relation between the cyclicality of fiscal policy and growth. A noteable exception is Aghion and Marinescu (2008), who find a positive effect of countercyclicality measures in a growth regression, using an (unbalanced) panel of annual data for 19 OECD countries from 1960 to 2007. Moreover, no previous study has considered the relations between cyclicality, volatility and growth in a joint empirical framework.

We first consider the effects of cyclicality on growth directly, running a cross-section regression of average growth of real GDP per worker over ( $\overline{\triangle \ln G D P P W}$ ) on the cyclicality of fiscal policy (CYC), again testing for differences in the effect of pro- and countercyclical policy:

$$
\overline{\Delta \ln G D P P W_{i}}=\delta_{0}+\delta_{1} \ln C Y C_{i}+\left(\delta_{1}^{\text {counter }} D_{i}^{\text {counter }} \ln C Y C_{i}\right)+\mathbf{w}_{i} \boldsymbol{\delta}+\vartheta_{i}
$$

The following standard controls $\left(\mathbf{w}_{i}\right)$ are included in our cross-country growth regression: the (log of the) initial level of real GDP per worker $\left(G D P P W^{\text {in }}\right)$, the average level of human capital in terms of educational attainment, i.e., the fraction of males above 25 with primary schooling $\left(H C^{\text {prim }}\right)$ and secondary schooling $\left(H C^{s e c}\right)$. Model (4) refers to the time period from 1960 to 2004 again; the cross-section dimension is slightly smaller now with 80 rather than 88 countries due to missing human capital data.

As in the volatility regressions in section III, the possible endogeneity of CYC is addressed by using the institutional variables NELEC and POLCON as instruments; and the fact that CYC is a calculated from fitted values of model (1) is accounted for by a weighted least squares approach, using the inverse of the variance of $C Y C$ as weight.

Columns (1a) and (1b) in Table 5 report the unweighted LS and TSLS estimates, allowing the effect of pro- and countercyclicality to differ. Columns (2a) and (2b) report the respective weighted estimates. In all specifications we find a significantly negative effect of cyclicality on economic growth. And as in section II, only the magnitude of cyclicality seems to matter: We find a negative effect of both pro-and countercyclicality on economic growth, and while the coefficient of countercyclical fiscal policy is smaller in magnitude, the difference in the coefficients is not significantly different from zero. This holds true for both the unweighted and the weighted estimates. According to the Hausman test there is no strong evidence for endogeneity of $C Y C$, though the (W)LS estimates of the parameter of $C Y C$ are always smaller in magnitude than the (W)TSLS estimates.

The results in Table 5 suggest a negative relation between the cyclicality of fiscal policy and economic growth. In the corresponding model (4), which omits output volatility (and further controls), the parameter of CYC $\left(\delta_{1}\right)$ captures all effects of cyclicality on economic growth, both through its relation with output volatility (direct and indirect through DISCR), 
through its relation with other variables affecting growth, as well as 'direct' effects of cyclicality on economic growth (if any). From an economic policy perspective, this might in fact be the most relevant question.

Table 5. Cyclicality of Fiscal Policy and Economic Growth

\begin{tabular}{|c|c|c|c|c|c|c|c|}
\hline & (1a) & (1b) & (2a) & $\begin{array}{c}\text { (2b) } \\
\text { WTSI S }\end{array}$ & (3a) & (3b) & $\begin{array}{c}\text { (3c) } \\
\text { UTSI S }\end{array}$ \\
\hline $\ln C Y C$ & $\begin{array}{l}-0.362^{* *} \\
(0.161)\end{array}$ & $\begin{array}{l}-0.767^{*} \\
(0.441)\end{array}$ & $\begin{array}{l}-0.341^{*} \\
(0.188)\end{array}$ & $\begin{array}{l}-0.606^{*} \\
(0.344)\end{array}$ & $\begin{array}{l}-0.297^{* *} \\
(0.118)\end{array}$ & $\begin{array}{l}-1.149^{* *} \\
(0.514)\end{array}$ & $\begin{array}{l}-0.439^{*} \\
(0.226)\end{array}$ \\
\hline$D^{\text {counter }} \ln C Y C$ & $\begin{array}{l}0.151 \\
(0.157)\end{array}$ & $\begin{array}{l}0.379 \\
(0.331)\end{array}$ & $\begin{array}{l}0.090 \\
(0.152)\end{array}$ & $\begin{array}{l}0.173 \\
(0.215)\end{array}$ & & & \\
\hline $\ln G D P P W^{\text {in }}$ & $\begin{array}{l}-0.748^{* * *} \\
(0.158)\end{array}$ & $\begin{array}{l}-0.798^{* * *} \\
(0.166)\end{array}$ & $\begin{array}{l}-1.046^{* * *} \\
(0.195)\end{array}$ & $\begin{array}{l}-1.016^{* * *} \\
(0.120)\end{array}$ & $\begin{array}{l}-0.748^{* * *} \\
(0.158)\end{array}$ & $\begin{array}{l}-0.895^{* * *} \\
(0.191)\end{array}$ & $\begin{array}{l}-1.087^{* * *} \\
(0.200)\end{array}$ \\
\hline $\ln H C^{\text {prim }}$ & $\begin{array}{l}0.524^{* *} \\
(0.218)\end{array}$ & $\begin{array}{l}0.568^{* *} \\
(0.244)\end{array}$ & $\begin{array}{l}1.134^{* * *} \\
(0.212)\end{array}$ & $\begin{array}{l}1.180^{* * *} \\
(0.236)\end{array}$ & $\begin{array}{l}0.532 \\
(0.217)\end{array}$ & $\begin{array}{l}0.688^{* *} \\
(0.318)\end{array}$ & $\begin{array}{l}1.163^{* * *} \\
(0.242)\end{array}$ \\
\hline $\ln H C^{s e c}$ & $\begin{array}{l}0.724^{* * *} \\
(0.136)\end{array}$ & $\begin{array}{l}0.646^{* * *} \\
(0.185)\end{array}$ & $\begin{array}{l}0.716^{* * *} \\
(0.177)\end{array}$ & $\begin{array}{l}0.567^{* *} \\
(0.279)\end{array}$ & $\begin{array}{l}0.726 \\
(0.132)\end{array}$ & $\begin{array}{l}0.515^{* *} \\
(0.223)\end{array}$ & $\begin{array}{l}0.663^{* * *} \\
(0.240)\end{array}$ \\
\hline Hausman $^{1)}$ (p-val.) & & $(0.467)$ & & $(0.182)$ & & $(0.015)$ & $(0.418)$ \\
\hline OID $^{2)}$ (p-val.) & & $(0.028)$ & & $(0.335)$ & & (0.929) & $(0.250)$ \\
\hline$R^{2}$ & 0.400 & 0.363 & 0.370 & 0.358 & 0.395 & 0.268 & 0.365 \\
\hline SEE & 1.051 & 1.100 & 1.203 & 1.121 & 1.048 & 1.332 & 1.107 \\
\hline Observations & 80 & 80 & 80 & 80 & 80 & 80 & 80 \\
\hline
\end{tabular}

Notes: Dependent variable is $\overline{\triangle \ln G D P P W}$. A constant is included in all models. ${ }^{*},{ }^{* *}$, ${ }^{* * *}$ denote significance at 10, 5, and 1 percent level respectively; robust standard errors in parenthesis. WLS denotes weighted least squares estimates, using the inverse of the variance of CYC as weight. (W)TSLS denotes (weighted) two stages least squares, using NELEC and POLCON as instruments for CYC. ${ }^{1)}$ Heterokedasticity-robust Hausman test for exogeneity; $\mathrm{H}_{0}$ : $\ln C Y C$ is exogenous. ${ }^{2)}$ Heteroskedasticityrobust test of overidentifying restrictions; $\mathrm{H}_{0}$ : NELEC, POLCON are valid instruments.

Nevertheless, we would like to provide a more detailed picture of the relation between cyclicality and growth. In particular, we also wish to answer the question whether CYC affects growth only through output volatility or also directly. Such a direct link could be motivated through the model by Aghion et al. (2006). Their argument is that credit constrained firms have a borrowing capacity that depends on current earnings, which are reduced in recessions, such that firms are less able to borrow in order to maintain growth enhancing investments. This reasoning suggests that countercyclicality may foster productivity growth by reducing the magnitude of the output loss induced by market failures (as credit market imperfections) in a recession. One could argue that such an effect should also hold for a given output volatility (i.e., controlling for output volatility). Regressing growth on cyclicality alone is not informative about the relevance of two potentially offsetting effects of cyclical fiscal policy: a 
negative effect by increasing volatility (suggested by the results in section III) and a possibly positive effect through reducing market failures due to credit market imperfections.

The empirical framework employed to address this question is sketched by Figure 2, which illustrates the interrelationships between the key variables in our empirical models. Potential endogeneity is indicated by reversed arrows (though the source of endogeneity is not necessarily simultaneity); relations between variables of the same equation (such as CYC and DISCR) are omitted for simplicity here.

Figure 2. Relationships between Key Variables in Empirical Models

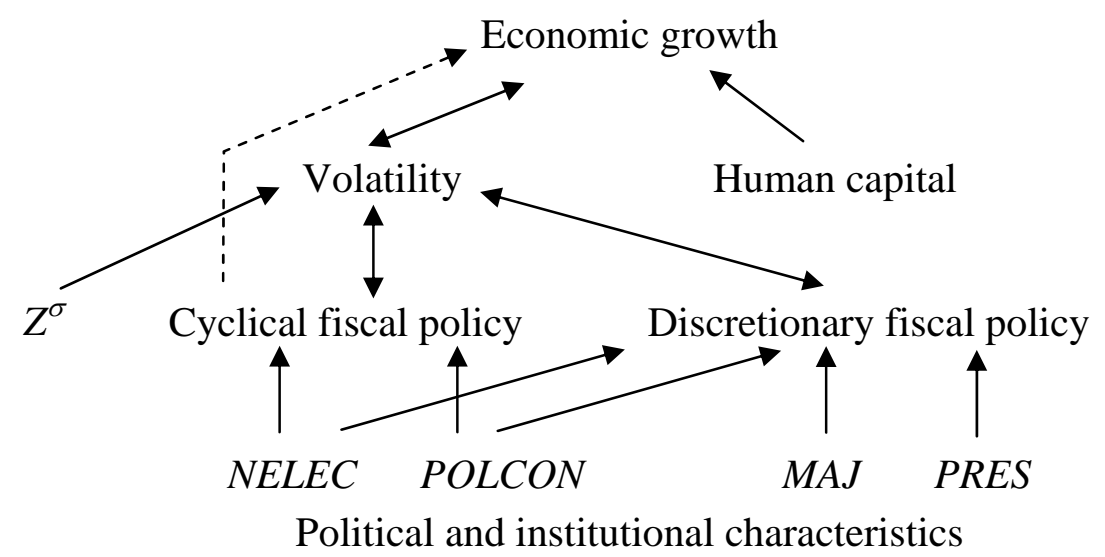

To test for a direct effect of cyclicality on growth, we first consider a model relating growth to output volatility (and controls). In a next step we add cyclicality as additional regressor (again considering potentially different effects of pro- and countercyclical policy):

$$
\overline{\Delta \ln G D P P W_{i}}=\varphi_{0}+\varphi_{1} \ln \sigma^{y}+\mathbf{w}_{i} \boldsymbol{\varphi}+\left(\delta_{1} \ln C Y C_{i}+\delta_{1}^{\text {counter }} D_{i}^{\text {counter }} \ln C Y C_{i}\right)+\zeta_{i}
$$

Column (1a) in Table 6 reports the least squares estimates of equation (5), column (1b) the TSLS estimates using the full set of institutional variables (NELEC, POLCON, MAJ, $P R E S)$ as instruments for volatility. ${ }^{11}$ Notice that the exogeneity of output volatility $\left(\sigma^{y}\right)$ is clearly rejected. Results of the TSLS estimates point to a negative effect of volatility on growth, consistent with our finding that cyclicality increases volatility (models (2) and (3)) and reduces growth (model (4)). The coefficient of output volatility (-2.968) suggests that an increase in volatility by one percent reduces average growth by some 0.3 percentage points. This is close to Fatas and Mihov (2003), who obtain a coefficient of -3.371 in a similar regression. We emphasize that results are very similar when MAJ and PRES are excluded from the set of instruments, or when CYC or DISCR are used as instruments directly. This is supportive of the finding in section III that the transmission mechanisms from political institutions to output volatility through cyclical and discretionary fiscal policy are very similar.

\footnotetext{
${ }^{11}$ Results for specifications without $C Y C$ are unweighted estimates.
} 
Table 6. Cyclicality of Fiscal Policy, Output Volatility, and Economic Growth

\begin{tabular}{|c|c|c|c|c|c|c|c|c|c|}
\hline & (1a) & (1b) & (1c) & (1d) & (2) & (3a) & (3b) & (3c) & (4) \\
\hline & LS & TSLS & TSLS & TSLS & TSLS & LS & TSLS & WTSLS & WTSLS \\
\hline $\ln \sigma^{y}$ & $\begin{array}{l}-0.994^{* *} \\
(0.302)\end{array}$ & $\begin{array}{l}-2.968^{* * *} \\
(0.107)\end{array}$ & $\begin{array}{l}-3.689^{*} \\
(2.128)\end{array}$ & $\begin{array}{l}-2.993^{* * *} \\
(0.955)\end{array}$ & $\begin{array}{l}-2.174^{*} \\
(1.196)\end{array}$ & $\begin{array}{l}-0.662^{* *} \\
(0.292)\end{array}$ & $\begin{array}{l}-2.101^{*} \\
(1.187)\end{array}$ & $\begin{array}{l}-1.173^{*} \\
(0.083)\end{array}$ & $\begin{array}{l}-1.416^{* *} \\
(0.611)\end{array}$ \\
\hline $\ln C Y C$ & & & & & & $\begin{array}{l}-0.100 \\
(0.109)\end{array}$ & $\begin{array}{l}-0.071 \\
(0.158)\end{array}$ & $\begin{array}{l}-0.194 \\
(0.133)\end{array}$ & $\begin{array}{l}-0.309 \\
(0.232)\end{array}$ \\
\hline$D^{\text {counter }} \ln C Y C$ & & & & & & & & & $\begin{array}{l}0.182 \\
(0.169)\end{array}$ \\
\hline $\ln H C^{\text {prim }}$ & $\begin{array}{l}0.551^{* *} \\
(0.203)\end{array}$ & $\begin{array}{l}0.697^{* * *} \\
(0.230)\end{array}$ & $\begin{array}{l}0.750^{* * *} \\
(0.274)\end{array}$ & $\begin{array}{l}0.699^{* * *} \\
(0.225)\end{array}$ & $\begin{array}{l}-0.569^{*} \\
(0.292)\end{array}$ & $\begin{array}{l}0.401^{* * *} \\
(0.146)\end{array}$ & $\begin{array}{l}0.587^{*} \\
(0.297)\end{array}$ & $\begin{array}{l}1.090^{* * * *} \\
(0.0186)\end{array}$ & $\begin{array}{l}1.127^{* * * *} \\
(0.190)\end{array}$ \\
\hline $\ln H C^{s e c}$ & $\begin{array}{l}0.580^{* * *} \\
(0.148)\end{array}$ & $\begin{array}{l}0.144^{* *} \\
(0.305)\end{array}$ & $\begin{array}{l}-0.015^{* *} \\
(0.491)\end{array}$ & $\begin{array}{l}0.138 \\
(0.270)\end{array}$ & $\begin{array}{l}0.446 \\
(0.241)\end{array}$ & $\begin{array}{l}0.598^{* * *} \\
(0.001)\end{array}$ & $\begin{array}{l}0.341 \\
(0.242)\end{array}$ & $\begin{array}{l}0.671^{* * *} \\
(0.149)\end{array}$ & $\begin{array}{l}0.061^{* * *} \\
(0.147)\end{array}$ \\
\hline OID $^{2)}$ (p-val.) & & $(0.760)$ & - & $(0.771)$ & $(0.644)$ & & $(0.607)$ & $(0.692)$ & $(0.673)$ \\
\hline$R^{2}$ & 0.409 & 0.316 & 0.278 & 0.314 & 0.430 & 0.537 & 0.463 & 0.417 & 0.406 \\
\hline SEE & 1.036 & 1.222 & 1.363 & 1.227 & 1.053 & 0.935 & 0.484 & 1.138 & 1.172 \\
\hline Observations & 80 & 80 & 80 & 80 & 78 & 78 & 78 & 78 & 78 \\
\hline
\end{tabular}

Notes: Dependent variable is $\overline{\Delta \ln G D P P W}$. A constant is included in all models. ${ }^{*}, * * * * *$ denote significance at 10 , 5 , and 1 percent level respectively; robust standard errors in parenthesis. WLS denotes weighted least squares estimates, using the inverse of the variance of CYC as weight. TSLS denotes (weighted) two stages least squares, using the following instruments for $\sigma^{y}$ : NELEC, POLCON, MAJ, PRES in (1b), $Z^{\sigma}$ in (1c), and both the institutional variables and $Z^{\sigma}$ in all other columns. ${ }^{1)}$ Heteroskedasticity-robust Hausman test for exogeneity; $\mathrm{H}_{0}$ : $\ln C Y C$, GSIZE (and $\ln$ DISCR) are exogenous. $\left.{ }^{2)}\right)$ Heteroskedasticity-robust test of overidentifying restrictions; $\mathrm{H}_{0}$ : NELEC, POLCON (MAJ, PRES ) and $\ln P O P, D E P, U R B A N$. 
The OID tests, reported at the bottom of Table 6, suggest that there is nothing wrong with our instruments. However, one might still argue that the power of this test is low and that the instruments, which are based on the respective country's institutional characteristics might be somehow associated with other country-specific institutions or policies affecting economic growth. We thus propose a new instrument for output volatility $\left(Z^{\sigma}\right)$, which is entirely unrelated to the respective country's characteristics. In particular, we suggest using, for each country $i$, the bilateral trade share weighted output volatility of all other countries $j(\neq i)$ in the sample. In a world of highly interdependent economies, where local shocks are propagated through the international economic system through trade and financial flows, we expect 'volatility spillovers' from foreign countries to be a relevant determinant of a country's own output volatility. However, in order to ensure exogeneity two modifications are made: First, the actual trade shares are replaced by predicted values from a bilateral gravity model including geographical variables only, an approach inspired by Frankel and Romer (1999). Second, the actual output volatility is replaced by predicted values from a regression of output volatility on (a constant and) the four institutional variables (NELEC, POLCON, MAJ, PRES). Appendix A3 gives more details on the construction of this instrument, referred to as $Z^{\sigma}$ henceforth. The validity of $Z^{\sigma}$ relies on the assumption that country i's geographical characteristics on the one hand and other countries' political institutions on the other hand are exogenous with respect to country i's economic growth in equation (4). In our view it is hard to think of convincing reasons why this assumption should be hurt.

The variable $Z^{\sigma}$ also turns out to be a relevant instrument for output volatility besides the four institutional variables (NELEC, POLCON, MAJ, PRES). In the first stage regression for model (5), including all four institutional variables, $Z^{\sigma}$ is significant at the one percent level. In fact, $Z^{\sigma}$ turns out to be the strongest instrument for output volatility besides political constraints (POLCON). This is an important result, since it implies that $Z^{\sigma}$ adds variation to identify the effect of output volatility in the growth regression (5) with CYC included as regressor, in addition to the identifying variation, which comes from the effects of institutions on volatility through on DISCR (which might be too closely associated with the effects of CYC on volatility) (see Figure 2).

Column (1c) shows the TSLS estimates of model (4), using only $Z^{\sigma}$ as instrument; the estimated effect of volatility is even larger in magnitude, though the estimates are less precise. Nevertheless, output volatility remains significant with a p-value of 0.087 . The fit of the model improves, when the four institutional variables are included as additional instruments (see column (1d)). Overall, the estimates of model (5) in columns (1b) to (1d), which differ only by the set of instruments used, are very similar. This is a reassuring result. In the following, we will use as instruments for volatility all four institutional variables (NELEC, POLCON, MAJ, PRES) as well as exogenous volatility spillovers $\left(Z^{\sigma}\right)$ to provide additional identifying variation. 
We next consider the robustness of the results with respect to controlling for institutional quality, which we measure using the government antidiversion policy (GADP) index by Hall and Jones (1999). Since institutional quality might be endogenous as a result of reverse causality - rich countries are generally better able to build up (costly) high quality institutions - we follow Hall and Jones (1999) and use the following proxy variables for Western influence as instruments for GADP: distance from equator, the fraction of a country's population speaking English as mother tongue, and the fraction of a country's population speaking one of the five European languages (English, French, German, Portuguese, Spain) as mother tongue. The results in column (2) show that the coefficient of GADP is positive as expected but insignificant. This might be due to inherently poor measurement of institutional quality and a mismatch in the time span covered by our growth regression (1960 to 2004) and the GADP measure, which refers to 1986 to 1995 . Moreover, the effect of institutional quality on per capita income is probably better estimated using a level rather than a growth rate approach (see Hall and Jones (1999), Alcalá and Ciccone (2004)). The most important result in the present context is that output volatility remains significant and negatively related to economic growth, even if institutional quality in terms of GADP is controlled for. ${ }^{12}$

We now test for a direct effect of cyclicality on growth. This means, that the variable $C Y C$ is included in the main equation (and instrumented by itself), whereas output volatility is instrumented by the institutional variables (NELEC, POLCON, MAJ, PRES) and exogenous volatility spillover $\left(Z^{\sigma}\right)$. Columns (3a), (3b), and (3c) show the LS, TSLS, and WTSLS estimates of equation (5) including institutional quality as control. ${ }^{13}$ (Results are very similar if $G A D P$ is omitted.) The estimates show no evidence for a direct effect. We reestimate model (3), allowing the effect of pro- and countercyclical policy to differ. Again no evidence for a direct effect of cyclicality on growth can be identified (see column (4)). This is a very robust result and also holds up for the unweighted regression or if the model is estimates least squares. We also explored the subsample stability with respect to the cross-country dimension (rich countries, excluding countries with large volatility or cyclicality coefficients) and the

\footnotetext{
${ }^{12}$ We also considered the variables OPEN or GSIZE as controls, since they are theoretically motivated determinants of output volatility and could be related to growth. This does not affect the results, which is not too surprising in light of the fact that the empirical association between volatility and these two variables is very weak (see the volatility regressions in section III).

Notice that, since CYC is included in the main model, the independent variation to identify the effect of volatility on growth comes from the instrument $Z^{\sigma}$ as well as from the effect of institutions on volatility through discretionary fiscal policy (see Figure 2). The latter is also apparent from the fact, that in a regression with output volatility as dependent variable, the political variables (MAJ, PRES, NELEC, POLCON) are jointly significant determinants of output volatility when CYC is controlled for, but they become insignificant if DISCR is added to the regressions as well. This suggests an alternative approach, using DISCR as instrument for $\sigma^{y}$ directly (instead of the instead of the institutional variables); results turned out almost identical and are not shown here for brevity.
} 
time dimension, considering the more recent time span 1980 to 2004. In none of the specifications, we could identify a direct effect of cyclicality besides output volatility, irrespective of whether we allow the effect of countercyclical policy to differ from that of procyclical policy or not. ${ }^{14}$

Overall, the findings in sections III and section IV provide a consistent picture. Cyclical as well as discretionary fiscal policy amplify output volatility (Tables 2 to 4), which is in turn negatively related to economic growth (Table 6). This also shows up in direct estimates of growth on cyclicality (Table 5). The effects found for rich countries are of the same order of magnitude but estimated less precisely, rendering the effects insignificant in some specifications with p-values slightly above the 10 percent level.

\section{Conclusions}

Previous studies found that discretionary fiscal policy, defined as policy unrelated to the business cycle, lowers output growth by increasing output volatility. Using a large crosssection of 88 countries over the period 1960 to 2004, the present paper provides comprehensive empirical evidence that this is also true for the second important element of fiscal policy, i.e., cyclical fiscal policy.

Building on Fatas and Mihov (2003), we suggest using information on the countries political and institutional characteristics to identify the causal effect of (endogenous) cyclicality on output volatility. In a second step, we consider the relation between economic growth and (endogenous) output volatility, induced by cyclical and discretionary fiscal policy.

We estimate simple average measures of cyclicality of government consumption over the period 1960 to 2004 for each of the 88 countries of our sample. The choice of an expenditure-based measure is due to data availability on the one hand but also motivated by the fact that it is more indicative of intentional fiscal policy (and less driven by automatic stabilizers). We find that cyclical fiscal policy constitutes a non-negligible share of overall fiscal policy, accounting for roughly one fifth in the total variation of government consumption in our sample. We then demonstrate that institutional variables (such as political constraints on policy implementation and the average number of elections) contain considerable information about the cross-country variation of fiscal cyclicality.

Using this exogenous variation, we identify a destabilizing effect of cyclical fiscal policy on economic activity, irrespective of whether the policy is pro- or countercyclical. This

\footnotetext{
${ }^{14}$ The robustness analysis for models (4) and (5) turns out very similar to that for output volatility in section II. Results for the effect of cyclicality on growth (Table 5) and volatility on growth (Tables 6) generally hold up but are less pronounced in the sample of rich countries, where p-values are slightly above 10 percent in some specifications.
} 
not only confirms the scepticisms against the usefulness of countercyclical fiscal policy as fine tuning instrument to smooth business cycles. It also implies that countercyclical policy the same amplifying effect on volatility as procyclical fiscal policy; in fact, we find some support for the hypothesis that cyclical fiscal policy affects volatility much in the same way as pure fiscal shocks (i.e., discretionary fiscal policy, unrelated to the cycle). Intentional cyclical policy measures - due to poor timing and lags in implementation and materialization (that will differ over alternative policy measures) - thus appear to spread over time in a way such that the implied average outcome is random with respect to (its effect on) the business cycle. According to this result, the way towards stabilization does not lead over more active countercyclical fiscal policy, but less cyclical fiscal policy at all.

The gains from this (passive) stabilization policy could be substantial in light of our finding that aggressive use of cyclical (as well as discretionary fiscal) policy has a negative effect on economic growth. This result is obtained both in a direct regression of growth on cyclicality and in a two stages least squares regression of growth on volatility, using the fiscal policy-related institutional variables as instrumental variables in the first stage regression. However, there is no evidence for a direct effect of cyclicality on economic growth, once output volatility is controlled for. These findings turn out robust across a large number of specifications and subsamples.

Overall, our results have an important policy implication: Economic growth could be enhanced by introducing fiscal rules, designed to limit the use of discretionary fiscal policy on the one hand (as already argued by Fatas and Mihov, 2003) but also the use cyclical fiscal policy on the other hand.

It should be added that - notwithstanding the robustness of our results with respect to subsample stability over the cross-country and time dimension - our cross-section estimates should be interpreted as averages over countries and time, not as economic laws that apply to every government at any time. Moreover, the use of government consumption as measure of fiscal policy- a choice required to obtain a relatively large sample of countries - limits the generality of the results. As a consequence, it would be interesting to investigate the effect of fiscal policy on volatility and growth for smaller groups of countries or single countries with more comprehensive, more detailed and higher frequency data on fiscal policy. Another question that remains to be addressed in future research is how existing fiscal rules affect the cyclical responsiveness of governments. Additional evidence on these issues would not only deepen our understanding of the channels, through which fiscal policy affects economic growth, but also help to answer the open question, how fiscal rules should be optimally designed in order to improve economic performance. 


\section{References}

Acemoglu, D., Johnson, S., Robinson, J., and Thaicharoen, Y. (2003). Institutional causes, macroeconomic symptoms: volatility, crises and growth. Journal of Monetary Economics, 50, 49-123.

Aghion, P., Angeletos, M., Banerjee, A., and Manova, K. (2005). Volatility and growth: credit constraints and productivity-enhancing investment. NBER Working Paper, No 11349.

Aghion, P. and Howitt, P. (2006). Appropriate growth policy: a unifying framework. Journal of the European Economic Association, Papers and Proceedings of the Twentieth Annual Congress of the European Economic Association 4(2-3), 269-314.

Aghion, P. and Marinescu, I. (2008). Cyclical budgetary policy and economic growth: what do we learn from OECD panel data? NBER Macroeconomics Annual, Cambridge, Mass: MIT Press, forthcoming.

Alcalá, F. and Ciccone, A. (2004). Trade and Productivity. Quarterly Journal of Economics, 119(2), 613-646.

Badinger, H. (2008). Fiscal rules, discretionary fiscal policy and macroeconomic stability: an empirical assessment for OECD countries. Applied Economics, 1-18. Published on 03 January 2008. DOI: 10.1080/00036840701367556.

Barro, R. J., and Lee, J.-W. (2002). International data on educational attainment: updates and implications. NBER Working Paper, No. 7911.

Barlevy, G. (2004). The costs of business cycles under endogenous growth. American Economic Review, 94(4), 964-990.

Caballero, R. and Hammour, M. (1991). The cleansing effect of recessions. American Economic Review, 84(5), 1350-1368.

Caballero, R.J. (2008). A comment on Aghion-Marinescu's “cyclical budgetary policy and economic growth: what do we learn from OECD panel data?” NBER Macroeconomics Annual, Cambridge, Mass: MIT Press, forthcoming.

Easterly, W. (2005). National policies and economic growth: a reappraisal. In: Aghion, P. and Durlauf, S. (eds.). Handbook of Economic Growth, Vol. 1, part 1, 1015-1059.

Fatas, A. and Mihov, I. (2003). The case for restricting fiscal policy discretion. Quarterly Journal of Economics, 4, 1419-1448.

Friedman, M. (1953). Essays in Positive Economics. Chicago: Chicago University Press.

Friedman, M. (1962). Capitalism and Freedom. Chicago: Chicago University Press.

Gali, J. (1994). Government size and macroeconomic stability. European Economic Review, 38, 748-756.

Gali, J. and Perotti, R. (2003). Fiscal policy and monetary integration in Europe. Economic Policy, 37, 533-572. 
Hall, R.E. (1991). Recessions as reorganizations. NBER Macroeconomic Annual 1991, Cambridge, Mass: MIT Press.

Hall, R.E. and Jones, C.I. (1999). Why do some countries produce so much more output per worker than others? Quarterly Journal of Economics, 114(1), 83-116.

Henisz, W.J. (2000). The institutional environment for economic growth. Economics and Politics, 12(1), 1-31.

Lane, P.R. (2003). The cyclical behaviour of fiscal policy: evidence from the OECD. Journal of Public Economics, 87, 2661- 2675.

Lucas, R.E. (1987). Models of Business Cycles. Basil Blackwell, Oxford.

Persson, T. and Tabellini, G. (2000). Political Economics: Explaining Economic Policy. MIT Press: Cambridge MA.

Persson, T. and Tabellini, G. (2001). Political institutions and policy outcomes: what are the stylized facts? CEPR Discussion Paper 2872.

Ramey, G. and Ramey, V. (1995). Cross-country evidence on the link between volatility and growth. American Economic Review, 85(3), 1138-1151.

Rodrick, D. (1998). Why do more open economies have bigger governments? Journal of Political Economy, 106, 997-1032.

Stiglitz, J. E. (1993). Endogenous growth and cycles. NBER Working Paper, No. 4286.

Talvi, E. and Vegh, C. (2005). Tax base variability and procyclical fiscal policy in developing countries. Journal of Development Economics, 78(1), 156-190,

Temple, J. (2003). The long-run implications of growth theories. Journal of Economic Surveys, 17(3) 497-510.

Tornell, A. and Lane, P.R. (1999). The voracity effect. American Economic Review, 89, 2246. 


\section{Appendix}

\section{A1. Sample Description}

The largest set of countries for which the required key variables are available comprises 88 countries. The list of countries is reported in Table A1, along with our estimates of the cyclicality parameter $\chi$ and the aggressiveness of discretionary fiscal policy (DISCR) from equation (1).

Table A1. Sample and Data on Output Volatility, Cyclical and Discretionary Fiscal Policy

\begin{tabular}{|c|c|c|c|c|c|c|c|}
\hline \multirow[b]{2}{*}{ country } & \multirow[b]{2}{*}{ time period (obs) } & \multicolumn{2}{|c|}{$\sigma^{\Delta \ln y}$} & \multicolumn{2}{|c|}{ Cyclicality $(\hat{\chi})$} & \multicolumn{2}{|c|}{ DISCR } \\
\hline & & 1960-2004 & 1980-2004 & 1960-2004 & 1980-2004 & 1960-2004 & 1980-2004 \\
\hline Argentina & $1960-2004(45)$ & 5.753 & 6.378 & 1.540 & 2.190 & 29.741 & 37.765 \\
\hline Australia & $1960-2004$ (45) & 1.840 & 1.807 & -0.375 & 0.009 & 3.086 & 1.965 \\
\hline Austria & $1960-2004(45)$ & 1.777 & 1.162 & 0.264 & 0.493 & 2.035 & 1.602 \\
\hline Burundi & $1960-2004$ (45) & 5.798 & 4.399 & 1.070 & 0.875 & 16.535 & 17.037 \\
\hline Belgium & $1960-2004(45)$ & 1.833 & 1.333 & -0.080 & -0.031 & 2.396 & 1.841 \\
\hline Benin & $1960-2004$ (45) & 3.099 & 3.058 & -0.034 & 0.038 & 8.456 & 9.478 \\
\hline Burkina Faso & $1960-2004(45)$ & 3.101 & 3.338 & 0.740 & 1.211 & 13.896 & 11.118 \\
\hline Bangladesh & $1960-2004(45)$ & 4.133 & 1.473 & 2.698 & 1.834 & 12.215 & 7.613 \\
\hline Bolivia & 1970-2004 (35) & 3.616 & 2.650 & 2.049 & 2.394 & 9.886 & 9.686 \\
\hline Brazil & $1960-2004$ (45) & 3.877 & 3.453 & 0.480 & 0.596 & 8.490 & 9.000 \\
\hline Centr. Afr. Rep. & 1960-2002 (43) & 4.034 & 4.678 & 0.891 & 1.095 & 11.129 & 12.311 \\
\hline Canada & 1965-2004 (40) & 1.982 & 2.122 & -0.464 & -0.283 & 1.871 & 1.767 \\
\hline Switzerland & $1960-2004(45)$ & 2.247 & 1.572 & 0.440 & 0.446 & 2.065 & 1.873 \\
\hline Chile & $1960-2004$ (45) & 4.879 & 4.565 & 0.824 & 0.428 & 8.088 & 5.652 \\
\hline Cote d'Ivoire & $1960-2004$ (45) & 5.214 & 4.104 & 1.270 & 1.059 & 9.886 & 10.647 \\
\hline Cameroon & 1965-2004 (40) & 5.818 & 5.306 & 0.988 & 1.004 & 8.558 & 10.020 \\
\hline Congo, Rep. & $1960-2004$ (45) & 5.500 & 6.002 & 0.461 & 0.448 & 17.857 & 22.703 \\
\hline Colombia & $1960-2004$ (45) & 2.084 & 2.095 & 0.686 & 0.693 & 9.275 & 9.074 \\
\hline Costa Rica & $1960-2004$ (45) & 3.241 & 3.585 & 1.016 & 1.177 & 5.458 & 6.202 \\
\hline Germany & $1960-2004$ (45) & 1.880 & 1.441 & 0.135 & 0.414 & 2.443 & 1.525 \\
\hline Denmark & $1960-2004$ (45) & 2.151 & 1.624 & 0.215 & -0.342 & 2.526 & 1.804 \\
\hline Dom. Republic & $1960-2004$ (45) & 5.080 & 3.624 & 0.728 & 3.369 & 21.349 & 19.347 \\
\hline Algeria & $1960-2004$ (45) & 7.147 & 2.591 & 0.931 & 0.551 & 9.207 & 7.538 \\
\hline Ecuador & $1960-2004$ (45) & 3.448 & 3.162 & 1.365 & 0.826 & 11.162 & 10.418 \\
\hline Egypt & $1960-2004$ (45) & 2.726 & 1.758 & 0.662 & -0.202 & 9.407 & 6.722 \\
\hline Spain & $1960-2004$ (45) & 2.326 & 1.574 & 0.656 & 0.430 & 2.659 & 2.223 \\
\hline Finland & $1960-2004$ (45) & 2.838 & 2.859 & -0.054 & -0.074 & 2.958 & 2.857 \\
\hline Fiji & $1960-2000(41)$ & 4.616 & 4.594 & 0.628 & 0.441 & 7.567 & 8.167 \\
\hline France & $1960-2004$ (45) & 1.585 & 1.138 & -0.281 & -0.432 & 1.411 & 1.186 \\
\hline Gabon & $1960-2000(41)$ & 9.397 & 5.968 & 0.616 & 0.683 & 20.247 & 17.257 \\
\hline United Kingdom & $1960-2004$ (45) & 1.735 & 1.754 & -0.262 & -0.273 & 2.320 & 1.914 \\
\hline Ghana & $1960-2004$ (45) & 4.592 & 3.603 & 1.776 & 3.716 & 14.358 & 14.671 \\
\hline Greece & $1960-2004$ (45) & 3.736 & 2.321 & 0.437 & 0.771 & 5.451 & 5.355 \\
\hline Guatemala & $1960-2004$ (45) & 2.458 & 2.178 & 1.121 & 2.170 & 8.607 & 9.144 \\
\hline Honduras & $1960-2004$ (45) & 2.886 & 2.423 & -0.110 & 0.596 & 7.057 & 7.434 \\
\hline Haiti & 1967-2003 (37) & 4.469 & 4.146 & 1.146 & 1.134 & 10.656 & 10.947 \\
\hline Indonesia & $1960-2004$ (45) & 3.981 & 4.444 & 1.560 & 1.453 & 14.998 & 8.224 \\
\hline India & $1960-2004$ (45) & 3.038 & 1.817 & 0.518 & 0.340 & 5.047 & 3.237 \\
\hline Ireland & 1960-2004 (45) & 2.595 & 2.930 & 0.602 & 0.610 & 3.561 & 3.373 \\
\hline Iceland & $1960-2004(45)$ & 3.701 & 2.914 & 0.860 & 0.669 & 3.904 & 3.244 \\
\hline
\end{tabular}


Table A1 (continued). Sample and Data on Output Volatility, Cyclical and Discretionary Fiscal Policy

\begin{tabular}{|c|c|c|c|c|c|c|c|}
\hline \multirow[b]{2}{*}{ country } & \multirow[b]{2}{*}{ time period (obs) } & \multicolumn{2}{|c|}{$\sigma^{\Delta \ln y}$ in percent } & \multicolumn{2}{|c|}{ Cyclicality $(\hat{\chi})$} & \multicolumn{2}{|c|}{$D I S C R$ in percent } \\
\hline & & $1960-2004$ & 1980-2004 & $1960-2004$ & $1980-2004$ & $1960-2004$ & $1980-2004$ \\
\hline Israel & 1960-2004 (45) & 3.331 & 2.118 & 1.181 & 1.334 & 9.928 & 6.283 \\
\hline Italy & $1960-2004(45)$ & 2.148 & 1.275 & 0.059 & 0.293 & 2.848 & 2.578 \\
\hline Jamaica & 1966-2004 (39) & 4.596 & 3.167 & 1.150 & 1.427 & 9.612 & 10.284 \\
\hline Japan & $1960-2004(45)$ & 3.453 & 1.791 & 0.128 & 0.123 & 2.205 & 0.879 \\
\hline Kenya & $1960-2004(45)$ & 4.562 & 1.982 & 1.202 & 1.789 & 5.977 & 4.584 \\
\hline Korea, Rep. & $1960-2004$ (45) & 3.441 & 3.782 & -0.281 & -0.121 & 6.844 & 3.137 \\
\hline Sri Lanka & $1960-2004(45)$ & 1.901 & 1.722 & 0.319 & 1.089 & 8.646 & 9.695 \\
\hline Lesotho & $1960-2004(45)$ & 6.383 & 3.844 & 0.239 & -0.350 & 15.132 & 9.970 \\
\hline Morocco & $1960-2004(45)$ & 4.449 & 4.796 & 0.700 & 0.549 & 7.568 & 4.719 \\
\hline Madagascar & $1960-2004$ (45) & 4.266 & 4.782 & 1.240 & 1.220 & 9.628 & 10.979 \\
\hline Mexico & $1960-2004(45)$ & 3.312 & 3.619 & 1.660 & 1.760 & 5.305 & 5.752 \\
\hline Mali & 1967-2004 (38) & 5.140 & 5.154 & 0.660 & 1.296 & 16.133 & 15.721 \\
\hline Mauritania & $1960-2004(45)$ & 5.890 & 3.270 & 0.635 & 1.900 & 17.809 & 18.398 \\
\hline Mauritius & $1980-2004$ (25) & 1.535 & 1.535 & 0.583 & 0.583 & 3.751 & 3.751 \\
\hline Malawi & $1960-2004(45)$ & 5.423 & 5.721 & -0.835 & -2.066 & 15.870 & 16.817 \\
\hline Malaysia & $1960-2004$ (45) & 3.385 & 3.971 & 0.229 & 0.548 & 8.451 & 8.308 \\
\hline Niger & $1960-2004(45)$ & 6.253 & 5.542 & 0.762 & 1.270 & 11.605 & 11.165 \\
\hline Nigeria & $1960-2004(45)$ & 7.186 & 5.100 & 0.429 & 0.814 & 19.854 & 22.460 \\
\hline Nicaragua & $1960-2004$ (45) & 6.895 & 4.200 & 0.277 & 1.633 & 19.112 & 22.562 \\
\hline Netherlands & $1960-2004$ (45) & 1.833 & 1.503 & 0.350 & -0.027 & 2.177 & 1.770 \\
\hline Norway & $1960-2004(45)$ & 1.554 & 1.618 & 0.631 & 0.023 & 3.675 & 3.982 \\
\hline New Zealand & $1971-2004(34)$ & 2.835 & 1.946 & 0.360 & 0.159 & 4.133 & 2.658 \\
\hline Pakistan & $1960-2004(45)$ & 2.187 & 1.793 & 0.975 & 1.308 & 8.104 & 7.276 \\
\hline Panama & $1960-2004(45)$ & 4.197 & 4.832 & 1.168 & 1.044 & 6.571 & 6.125 \\
\hline Peru & $1960-2004(45)$ & 5.038 & 6.201 & 1.248 & 1.381 & 9.718 & 7.948 \\
\hline Philippines & $1960-2004$ (45) & 3.027 & 3.629 & 1.261 & 1.490 & 5.344 & 5.665 \\
\hline Pap. New Guinea & 1961-1999 (39) & 4.610 & 5.118 & 1.042 & 0.893 & 8.776 & 9.588 \\
\hline Portugal & $1960-2004(45)$ & 3.295 & 2.521 & 0.750 & 1.261 & 3.549 & 2.571 \\
\hline Paraguay & $1960-2004$ (45) & 3.793 & 3.768 & 0.469 & 0.988 & 9.713 & 10.104 \\
\hline Rwanda & $1960-2004(45)$ & 11.997 & 14.623 & 1.171 & 1.303 & 16.300 & 16.653 \\
\hline Senegal & $1960-2004(45)$ & 4.173 & 3.777 & 0.827 & 0.033 & 18.002 & 5.998 \\
\hline Singapore & $1960-2004$ (45) & 4.175 & 3.832 & 0.043 & -0.339 & 6.823 & 7.359 \\
\hline El Salvador & $1960-2004(45)$ & 3.834 & 4.215 & 0.561 & 0.319 & 5.802 & 5.548 \\
\hline Sweden & $1960-2004$ (45) & 1.925 & 1.837 & 0.032 & 0.050 & 2.252 & 1.828 \\
\hline Syr. Arab Rep. & $1960-2004(45)$ & 7.809 & 5.298 & 0.569 & -0.005 & 9.749 & 9.548 \\
\hline Chad & $1960-2004(45)$ & 8.186 & 8.773 & 0.064 & 0.027 & 14.689 & 19.314 \\
\hline Togo & $1960-2004(45)$ & 6.131 & 6.234 & 0.174 & 0.410 & 17.114 & 13.173 \\
\hline Thailand & $1960-2004(45)$ & 3.635 & 4.436 & 0.519 & 0.446 & 4.761 & 3.667 \\
\hline Trin. and Tobago & $1960-2004$ (45) & 4.749 & 5.666 & 1.195 & 1.269 & 11.929 & 13.900 \\
\hline Tunisia & $1961-2004(44)$ & 3.343 & 2.557 & 0.443 & -0.019 & 5.614 & 2.266 \\
\hline Turkey & 1968-2004 (37) & 4.147 & 4.637 & 0.629 & 0.602 & 7.737 & 8.357 \\
\hline Uruguay & $1960-2004(45)$ & 4.744 & 5.812 & 0.989 & 0.974 & 10.328 & 5.996 \\
\hline United States & $1960-2004$ (45) & 1.906 & 1.820 & -0.048 & -0.091 & 1.967 & 1.310 \\
\hline Venezuela & $1960-2004$ (45) & 4.949 & 5.938 & 1.616 & 1.913 & 16.543 & 20.776 \\
\hline South Africa & $1960-2004(45)$ & 2.525 & 2.658 & 0.892 & 0.664 & 4.724 & 3.700 \\
\hline Congo, Dem. Rep. & 1960-2004 (45) & 6.079 & 5.363 & 1.570 & 1.425 & 26.618 & 32.791 \\
\hline Zambia & $1960-2004(45)$ & 4.703 & 3.919 & 1.485 & 1.928 & 21.520 & 24.135 \\
\hline Zimbabwe & $1960-2004(45)$ & 5.828 & 5.811 & 0.335 & 0.339 & 12.693 & 15.324 \\
\hline Correlation & & 0.8 & 42 & & & & 35 \\
\hline
\end{tabular}




\section{A2. Variable Definitions and Data Sources}

DEP dependency ratio, defined as ratio of people younger than 15 and older than 64 to working age population (people from 15 to 64). Source: World Development Indicators (WDI).

GC real general government consumption in national currency. Source: WDI.

GDPPC real GDP per capita in PPP\$. Source: Penn World Tables (PWT) 6.2.

GDPPW real GDP per worker in PPP\$. Source: PWT 6.2.

GSIZE ratio of government consumption to GDP.

$H C^{\text {prim }}$ primary educational attainment, defined as fraction of males above 25 with primary schooling. Source: Barro and Lee (2002).

$H^{\text {sec }} \quad$ secondary educational attainment, defined as fraction of males above 25 with secondary schooling. Source: Barro and Lee (2002).

MAJ zero-one dummy for electoral system (1 for majoritarian, 0 for proportional). Sources: Person and Tabellini (2001), Database of Political Institutions.

NELEC average number of elections. Sources: Database of Political Institutions.

OPEN ratio of imports plus exports to GDP. Source: PWT 6.2.

POLCON index of political constraints. Source: Henisz (2000).

POP population in million persons. Source: WDI.

PRES zero-one dummy for political regime (1 for presidential, 0 for parliamentary). Source: Person and Tabellini (2001), Database of Political Institutions.

$U R B \quad$ ratio of urban population to total population. Source: WDI.

$y \quad$ real GDP in national currency per capita; $y=Y / P O P$. Source: WDI.

$Y \quad$ real GDP in national currency. Source: WDI. 


\section{A3. Construction of Instrument for Output Volatility}

The instrument for output volatility $Z^{\sigma}$ takes the following value for country $i$ :

$$
Z_{i}^{\sigma}=\sum_{j=1, j \neq i}^{N} \hat{w}_{i j} \ln \hat{\sigma}_{j}^{y}
$$

where $\hat{\sigma}_{j}^{y}$ is the 'institutionally induced' output volatility of country $j$, obtained by forming predicted values from a cross-country regression of $\ln \sigma^{y}$ on a constant and the four institutional variables NELEC, POLCON, MAJ, and PRES.

The weights $\hat{w}_{i j}$ are obtained as predicted values of the bilateral trade shares (imports plus exports as a share of GDP) from a gravity model including geographical variables only. ${ }^{15}$ In line with Frankel and Romer (1999) the following explanatory variables are included in the geographical gravity model: the size of countries $i$ and $j$ (measured by area and population), distance between countries $i$ and $j$, a common border dummy, a landlocked dummy, as well as interaction terms of all variables with the common border dummy. The gravity model is estimated for our sample of 7656 bilateral trade flows (on which 6393 nonzero observations are available), using average values from the period 1980 to 1990 (roughly corresponding to our sample midpoint).

Both models, the regression of volatility on the four institutional variables and the geographical gravity model, perform reasonably well with an $R^{2}$ (F-statistic) of 0.493 (20.191) and 0.347 (261.051) respectively. The correlation between $Z^{\sigma}$ and the trade share weighted volatility based on actual rather than predicted values is 0.602 . Finally, the correlation between $Z^{\sigma}$ and output volatility is 0.336 .

\footnotetext{
${ }^{15}$ This approach is inspired by Frankel and Romer (1999), who use the country-specific sum of predicted bilateral trade shares from a geographical gravity model - an aggregate measure of proximity - as an instrument in a cross-country regression of per capita income on (endogenous) trade and country size. The difference is that we use the bilateral predicted values as weights rather than summing them up to an aggregate proximity measure.
} 


\section{CESifo Working Paper Series}

for full list see www.cesifo-group.org/wp

(address: Poschingerstr. 5, 81679 Munich, Germany, office@cesifo.de)

2204 P. Mohnen, F. C. Palm, S. Schim van der Loeff and A. Tiwari, Financial Constraints and other Obstacles: Are they a Threat to Innovation Activity?, January 2008

2205 Sascha O. Becker and Mathias Hoffmann, Equity Fund Ownership and the CrossRegional Diversification of Household Risk, January 2008

2206 Pedro R. D. Bom and Jenny E. Ligthart, How Productive is Public Capital? A MetaAnalysis, January 2008

2207 Martin Werding, Ageing and Productivity Growth: Are there Macro-level Cohort Effects of Human Capital?, January 2008

2208 Frederick van der Ploeg and Steven Poelhekke, Globalization and the Rise of MegaCities in the Developing World, February 2008

2209 Sara Biancini, Regulating National Firms in a Common Market, February 2008

2210 Jin Cao and Gerhard Illing, Liquidity Shortages and Monetary Policy, February 2008

2211 Mathias Kifmann, The Design of Pension Pay Out Options when the Health Status during Retirement is Uncertain, February 2008

2212 Laszlo Goerke, Tax Overpayments, Tax Evasion, and Book-Tax Differences, February 2008

2213 Jun-ichi Itaya and Heinrich W. Ursprung, Price and Death, February 2008

2214 Valentina Bosetti, Carlo Carraro and Emanuele Massetti, Banking Permits: Economic Efficiency and Distributional Effects, February 2008

2215 Assar Lindbeck, Mårten Palme and Mats Persson, Social Interaction and Sickness Absence, February 2008

2216 Gary E. Bolton and Axel Ockenfels, The Limits of Trust in Economic Transactions Investigations of Perfect Reputation Systems, February 2008

2217 Hartmut Egger and Peter Egger, The Trade and Welfare Effects of Mergers in Space, February 2008

2218 Dorothee Crayen and Joerg Baten, Global Trends in Numeracy 1820-1949 and its Implications for Long-Run Growth, February 2008

2219 Stephane Dees, M. Hashem Pesaran, L. Vanessa Smith and Ron P. Smith, Identification of New Keynesian Phillips Curves from a Global Perspective, February 2008 
2220 Jerome L. Stein, A Tale of Two Debt Crises: A Stochastic Optimal Control Analysis, February 2008

2221 Michael Melvin, Lukas Menkhoff and Maik Schmeling, Automating Exchange Rate Target Zones: Intervention via an Electronic Limit Order Book, February 2008

2222 Raymond Riezman and Ping Wang, Preference Bias and Outsourcing to Market: A Steady-State Analysis, February 2008

2223 Lars-Erik Borge and Jørn Rattsø, Young and Old Competing for Public Welfare Services, February 2008

2224 Jose Apesteguia, Steffen Huck, Jörg Oechssler and Simon Weidenholzer, Imitation and the Evolution of Walrasian Behavior: Theoretically Fragile but Behaviorally Robust, February 2008

2225 Walter Krämer, Long Memory with Markov-Switching GARCH, February 2008

2226 António Afonso and Christophe Rault, What do we really Know about Fiscal Sustainability in the EU? A Panel Data Diagnostic, February 2008

2227 Sergey M. Kadochnikov and Igor M. Drapkin, Market Structure, Technological Gap and Vertical Linkage Effects from Foreign Direct Investment, February 2008

2228 Guglielmo Maria Caporale, Davide Ciferri and Alessandro Girardi, Fiscal Shocks and Real Exchange Rate Dynamics: Some Evidence for Latin America, February 2008

2229 Scott Alan Carson, Geography and Insolation in $19^{\text {th }}$ Century US African-American and White Statures, February 2008

2230 Wolfgang Buchholz and Jan Schumacher, Discounting and Welfare Analysis Over Time: Choosing the $\eta$, February 2008

2231 M. Hashem Pesaran, Christoph Schleicher and Paolo Zaffaroni, Model Averaging in Risk Management with an Application to Futures Markets, February 2008

2232 Wilhelm Kohler, Offshoring: Why Do Stories Differ?, February 2008

2233 Stefan Bach, Giacomo Corneo and Viktor Steiner, Effective Taxation of Top Incomes in Germany, 1992-2002, February 2008

2234 Robert S. Chirinko, $\sigma:$ The Long And Short Of It, February 2008

2235 Volker Grossmann and Holger Strulik, Should Continued Family Firms Face Lower Taxes than other Estates?, February 2008

2236 Guido Tabellini, The Scope of Cooperation: Values and Incentives, February 2008

2237 Heinrich W. Ursprung and Christian Wiermann, Reputation, Price, and Death: An Empirical Analysis of Art Price Formation, March 2008 
2238 Hans Fehr and Christian Habermann, Private Retirement Savings in Germany: The Structure of Tax Incentives and Annuitization, March 2008

2239 Joseph Francois and Ian Wooton, Market Structure and Market Access, March 2008

2240 Hiroyuki Kasahara and Beverly Lapham, Productivity and the Decision to Import and Export: Theory and Evidence, March 2008

2241 Gary E. Bolton and Axel Ockenfels, Does Laboratory Trading Mirror Behavior in Real World Markets? Fair Bargaining and Competitive Bidding on EBay, March 2008

2242 Atsushi Oshima, B. Ravikumar and Raymond Riezman, Entrepreneurship, Organization Capital and the Evolution of the Firm, March 2008

2243 Walter Krämer and Sebastian Schich, Large-Scale Disasters and the Insurance Industry, March 2008

2244 Leif Danziger, Adjustment Costs, Inventories and Output, March 2008

2245 Anne van Aaken, Lars P. Feld and Stefan Voigt, Power over Prosecutors Corrupts Politicians: Cross Country Evidence Using a New Indicator, March 2008

2246 Hans-Christian Heinemeyer, Max-Stephan Schulze and Nikolaus Wolf, Endogenous Borders? The Effects of New Borders on Trade in Central Europe 1885-1933, March 2008

2247 Johannes Becker and Clemens Fuest, Tax Competition - Greenfield Investment versus Mergers and Acquisitions, March 2008

2248 Giorgio Bellettini and Hubert Kempf, Why not in your Backyard? On the Location and Size of a Public Facility, March 2008

2249 Jose Luis Evia, Roberto Laserna and Stergios Skaperdas, Socio-Political Conflict and Economic Performance in Bolivia, March 2008

2250 Bas Jacobs and A. Lans Bovenberg, Optimal Taxation of Human Capital and the Earnings Function, March 2008

2251 Jan-Egbert Sturm and Timo Wollmershäuser, The Stress of Having a Single Monetary Policy in Europe, March 2008

2252 Guido Schwerdt, Labor Turnover before Plant Closure: 'Leaving the Sinking Ship' vs. 'Captain Throwing Ballast Overboard', March 2008

2253 Keith E. Maskus and Shuichiro Nishioka, Development-Related Biases in Factor Productivities and the HOV Model of Trade, March 2008

2254 Jeremy Edwards and Sheilagh Ogilvie, Contract Enforcement, Institutions and Social Capital: the Maghribi Traders Reappraised, March 2008 
2255 Imed Drine and Christophe Rault, Purchasing Power Parity for Developing and Developed Countries. What can we Learn from Non-Stationary Panel Data Models?, March 2008

2256 Scott Alan Carson, Health, Wealth and Inequality: a Contribution to the Debate about the Relationship between Inequality and Health, March 2008

2257 C.A.E. Goodhart, The Regulatory Response to the Financial Crisis, March 2008

2258 Stefan Bauernschuster, Oliver Falck and Stephan Heblich, The Impact of Continuous Training on a Firm's Innovations, March 2008

2259 Michael Grimm and Stephan Klasen, Geography vs. Institutions at the Village Level, March 2008

2260 Fwu-Ranq Chang, Property Insurance, Portfolio Selection and their Interdependence, March 2008

2261 J. Atsu Amegashie and Marco Runkel, The Paradoxes of Revenge in Conflicts, March 2008

2262 Hans Jarle Kind, Marko Koethenbuerger and Guttorm Schjelderup, Efficiency Enhancing Taxation in Two-sided Markets, March 2008

2263 M. Hashem Pesaran, Til Schuermann and L. Vanessa Smith, Forecasting Economic and Financial Variables with Global VARs, March 2008

2264 Volker Grossmann, Entrepreneurial Innovation and Sustained Long-run Growth without Weak or Strong Scale Effects, March 2008

2265 Robert S. Chirinko and Huntley Schaller, The Irreversibility Premium, March 2008

2266 Andrea Galeotti and José Luis Moraga-González, Platform Intermediation in a Market for Differentiated Products, April 2008

2267 Torben M. Andersen and Michael Svarer, The Role of Workfare in Striking a Balance between Incentives and Insurance in the Labour Market, April 2008

2268 Harald Badinger, Cyclical Fiscal Policy, Output Volatility, and Economic Growth, April 2008 